$1-2013$

\title{
A Dialogical Approach to Trade and Environment
}

Elizabeth Trujillo

Texas A\&M University School of Law, etrujillo@law.tamu.edu

Follow this and additional works at: https://scholarship.law.tamu.edu/facscholar

Part of the Law Commons

\section{Recommended Citation}

Elizabeth Trujillo, A Dialogical Approach to Trade and Environment, 16 J. Int'I Econ. L. 535 (2013).

Available at: https://scholarship.law.tamu.edu/facscholar/800

This Article is brought to you for free and open access by Texas A\&M Law Scholarship. It has been accepted for inclusion in Faculty Scholarship by an authorized administrator of Texas A\&M Law Scholarship. For more information, please contact aretteen@law.tamu.edu. 


\title{
A DIALOGICAL APPROACH TO TRADE AND ENVIRONMENT
}

\author{
Elizabeth Trujillo*
}

\begin{abstract}
Traditionally, supporters of free trade and environmentalists have regarded each other as the obstacle to development, and both sides have very different views as to what constitutes development. This article considers the various dimensions to international trade governance in the context of the environment and draws from the dialogic theory in comparative constitutional law to frame trade governance regarding the environment in a new way. It uses a dialogical approach to highlight primarily three characteristics of the international trade regime that has fostered enhanced cross-fertilization of trade and environmental issues: (i) the adjudicatory capacity of the World Trade Organization (WTO) and preferential trade agreements (PTAs), (ii) the administrative capacity of the WTO and PTAs, and (iii) the fragmentary nature of trade governance. This approach highlights ways in which these three dynamics have allowed for heightened 'cross-fertilization' of environmental concerns into the trade framework, stimulating a form of transnational regulatory bargaining with respect to environmental issues vis-à-vis trade that reaches beyond the trade realm. Though a close look at these characteristics also illuminates the important role of free trade more generally and the WTO more specifically, in setting a normative vision of environmental sustainability, it also shows that trade regimes are limited in setting a course for addressing sustainable development. In particular, free trade says little about what constitutes sustainable development, especially when also faced with

\footnotetext{
* Professor of Law at Suffolk University School of Law in Boston. E-Mail: etrujillo@suffolk.edu. She was a Visiting Scholar at Harvard Law School in 2011-12. Recent drafts were presented at faculty workshops at the Harvard Law School 2013 IL-IR Workshop, Northeastern School of Law, and Brooklyn Law School. Earlier drafts of this article have been presented at: 2011 IGLP Harvard Workshop, the Law and Society 2009 Annual Meeting, SMU-Dedman 2010 Faculty Workshop ABILA 2010 International Law Week-end, University of Minnesota for the 2010 ASIL-IELG Biennial Meeting, and MSU 2011 International Law Journal Symposium. The author would like to thank participants in the above mentioned events as well as Brook Baker, Sungjoon Cho, Frank Garcia, David Kennedy, Andrew Lang, Michael Trebilcock, Mark Wu, and Margaret Young for their comments on this piece. The author would also like to thank Kimberley Buder, Brian Haynes, and Greg Vanden-Eykel for their invaluable research assistance as well as Suffolk University Law School for its continuous support. Special thanks to my research assistant, Bryan Connor, for his assistance in editing, and Richard Buckingham for his consistently reliable library research.
} 
the different challenges for economic development in the developed and developing countries.

The Parties to this Agreement,

Recognizing that relations in the field of trade and economic endeavor should be conducted with a view to ... expanding the production of and trade in goods and services, while allowing for the optimal use of the world's resources in accordance with the objective of sustainable development, seeking to protect and preserve the environment and to enhance the means for doing so in a manner consistent with their respective needs and concerns at different levels of economic development...

Preamble, The WTO Agreement (April, 15, 1994)

\section{INTRODUCTION}

Concerns for the environment and sustainability can not be ignored, especially in the midst of so many crises of late: BP oil spill, Japan's earthquake and tsunami leading to a possible nuclear meltdown, rising ocean temperatures, and climate change phenomena more generally. With the emerging economies continuing to develop at significant speeds, international economic institutions increasingly find themselves at the crossroads of economic development and the preservation of natural resources. The World Trade Organization (WTO) is once again at the forefront of the trade and environment interface with the recent three latest labeling cases: United States Concerning the Importation, Marketing and Sale of Tuna and Tuna Products; United States - Measures Affecting the Production and Sale of Clove Cigarettes; and US-Certain Country of Origin Labeling (COOL). ${ }^{1}$ Many have argued that the WTO should expand its jurisdiction to deal with nontrade matters such as the environment in more formal ways. Over the years, there have been strides in this direction, with WTO adjudication of environmental regulations and WTO committee work on trade and environment issues. ${ }^{2}$

The WTO has played both an administrative and adjudicatory function with respect to trade matters and in turn, has become an agent of global governance in this regard. The formal structure of the WTO, including its dispute settlement bodies, has made it a natural focal point for those searching for a global governing structure for trade and environmental issues. The adjudicatory aspect of WTO panels, along with its binding Covered Agreements setting up rules for trade, provides the WTO with a veil of

${ }^{1}$ United States - Measures Affecting the Production and Sale of Clove Cigarettes, WT/DS406/R, 2 September 2011 (hereinafter, US - Clove Cigarettes); US-Certain Country of Origin Labeling (COOL) (Canada), WT/DS384/8 and US-COOL (Mexico), WT/DS386/7.

${ }^{2}$ Doha Agenda and Committee on Trade and Environment available at http://www.wto.org/english/tratop_e/envir_e/envir_e.htm. 
legitimacy and formality that can not be ignored. ${ }^{3}$ Its adjudicatory capacity enhances the legalization of the WTO. ${ }^{4}$ However, it is not only a source for law-making processes concerning trade, but also acts as a catalyst for more discourse and negotiation around economic development and environmental sustainability, two concepts that are not easily compatible.

This article uses a dialogical approach to highlight the relevance of the WTOs institutional framework, with its adjudicatory and administrative functions ${ }^{5}$ in fostering the cross-fertilization of trade and environmental issues ${ }^{6}$ and the transference of related transnational norms across jurisdictional lines and topical domains. ${ }^{7}$ The adjudicatory function of WTO panels, for example, has fostered judicial 'cross-fertilization' of trade and environmental issues and a convergence of the global and the domestic, as WTO judges grapple with domestic environmental regulation. ${ }^{8}$

${ }^{3}$ Kenneth W. Abbott et al., 'The Concept of Legalization', 54 International Organization 401 (2000) (recognizing that 'legalization' consists of (i) obligations of rules, (ii) the precision of those rules in establishing conduct, and (iii) the delegation to third parties to interpret and/or enforce the rules, but also is not necessarily separate from political bargaining).

4 See Beth Simmons, 'The Legalization of International Monetary Affairs', 53 International Organization 573, 574 available at http://www.jstor.org/stable/2601345 (with respect to the IMF rules, stating that 'legalization strengthens commitment. It is this quality that makes formal treaty arrangements desirable in the first place'.).

5 This article, while recognizing that the adjudicatory and non-adjudicatory capacities of the WTO may constitute part of a global administrative space, it separates out the two in order to highlight the different functions and purposes of both areas for trade regulation. See Benedict Kingsbury, Nico Krisch and Richard B. Stewart, 'The Emergence of Global Administrative Law', 68 Law and Contemporary Problems 15 (2005), at 17 (providing a taxonomy for a global administrative space that includes rule-making and administrative adjudication between competing interests and regulatory and management within 'administrative action').

${ }^{6}$ See Sungjoon Cho, 'Linkage of Free Trade and Social Regulation: Moving Beyond the Entropic Dilemma', 6 Chicago Journal of International Law 625 (2005), at 626 (discussing the linkages between competing values of free trade and social regulation).

7 See Ruti Teitel, 'Comparative Constitutional Law in a Global Age', 117 Harvard Law Review 2570 (2004), at 2584-87 (discussing 'the dialogical approach' in comparative constitutionalism as a contemporary means of grounding 'comparativism ... in the processes of judicial review'). See Anne-Marie Slaughter, 'A Global Community of Courts', 44 Harvard International Law Journal 191 (2003), at 193-94 (discussing 'transnational litigation' as consisting of domestic and international tribunals that involves not only private parties but also cases between states, and states and individuals as well as between individuals transnationally); Anne-Marie Slaughter, 'Judicial Globalization', 40 Virginia Journal of International Law 1103 (2000) (describing 'judicial globalization' as a process of transnational judicial interaction); Melissa Waters, 'Mediating Norms and Identity: The Role of Transnational Judicial Dialogue in Creating and Enforcing International Law', 93 Georgetown Law Journal 487, 489-90 (proposing that, primarily with regard to constitutional issues, "transnational judicial dialogue" is the engine by which domestic courts collectively engage in the co-constitutive process of creating and shaping international legal norms and, in turn, ensuring that those norms shape and inform domestic courts'.).

${ }^{8}$ See Ruti Teitel and Robert Howse, 'Cross-Judging: Tribunalization in a Fragmented but Interconnected Global Order', 7-12 (2011) (illustrating ways in which adjudication across related but different jurisdictional capacities highlights a common value to which each siloed area speaks to; that is, 'humanity law'), draft available at http://ssrn.com/abstract=1334289. 
A dialogic approach has been traditionally associated with judicial 'dialogue', as a means of framing the role of courts vis à vis other branches and levels of government. ${ }^{9}$ In this framework, courts not only interpret laws, but also 'engage' with the work of other branches of government, for example agencies in the context of administrative law. ${ }^{10}$ They have an ongoing dialogue with non-judicial actors and may even engage with other comparable jurisprudence. ${ }^{11}$ In the international, dialogical approaches have taken hold in better understanding the way in which international courts interact with each other and with national courts. ${ }^{12}$ In particular, it attempts to provide metaphorical framing for 'judicial comity', where unrelated courts may refer to one another's decisions to assist them with new problems of transnational appeal. ${ }^{13}$ In these ways, courts may foster international reciprocity of international norms and enhance the ability of these norms to travel across jurisdictional lines, even taking hold domestically. ${ }^{14}$

While this article does not attempt to elaborate on the theory of a dialogic approach, it draws from key characteristics of this approach that are applicable to framing trade governance regarding the environment in a new way. First, a dialogic approach considers the ways in which different legal norms interact. ${ }^{15}$ These interactions allow for cross-fertilization of trade and non-trade issues. Second, a dialogic approach highlights the dynamic process of the judiciary 'engaging' with non-judiciary actors. ${ }^{16}$ Trade dispute settlement bodies have had to decide the viability of non-tariff trade barriers under trade jurisprudence. This process has in fact forced trade adjudicators into legal areas outside the trade scope, including environmental law and domestic regulation. Such engagement has not only allowed for

${ }^{9}$ See e.g. Jay Tidmarsh, 'A Dialogic Defense of Alden', 75 Notre Dame Law Review 1161 (2000), at 1163 (stating that a dialogic theory contends 'perhaps counterintuitively, that the fundamental constitutional role of each court system is to engage the other system in a dialogue about the extent and shape of the other system's rights, obligations, and entitlements.').

${ }^{10}$ See also, Emily Hammond Meazell, 'Deference and Dialogue in Administrative Law', 111 Columbia Law Review 1722 (2011), at 1734.

${ }^{11}$ Sujit Choudhry, 'Globalization in Search of Justification: Toward a Theory of Comparative Constitutional Interpretation', 74 Indiana Law Journal 819 (1999), at 825-26.

${ }^{12}$ See Slaughter, 'Judicial Globalization', above n 7. See also, Robert Ahdieh, 'Between Dialogue and Decree: International Review of National Courts', 79 NYU Law Review 2029 (2004) (discussing Chapter 11 NAFTA investor-state disputes as containing elements of 'judicial dialogue and transnational comity').

${ }^{13}$ See Anne-Marie Slaughter, 'Court to Court', 92 American Journal of International Law 708 (1998), at $709-11$.

${ }^{14}$ See Anne-Marie Slaughter, 'A Typology of Transjudicial Communication', 29 University of Richmond Law Review 99 (1994), at 115-17 (discussing how transnational judicial communication can promote 'reciprocal international obligations').

${ }^{15}$ See Ibid at 117-19 (proposing that transnational judicial communication allows for norms to travel across legal systems and therefore, enhance cross-fertilization for dissimilar areas of the law).

${ }^{16}$ See Tidmarsh, above $\mathrm{n} 9$. 
cross-fertilization, but also brought environmental policy into the same discourse of international trade in concrete ways; and in turn, impacted domestic environmental policy and foreign policy. ${ }^{17}$ Third, a dialogic approach provides a prism through which to see the various dimensions of interactions between trade and environmental issues. In this approach, there is no hierarchy per se in which to invoke various legal norms - a trade dispute settlement body may consider legal norms in or outside of trade or in other international treaties and international environmental communities may be borrowed from trade norms. ${ }^{18}$ Because of the lack of hierarchy, the fragmentation in trade adjudication becomes particularly relevant in understanding the ways in which environmental issues and trade cross-fertilize, especially with respect to vertical and horizontal forms of judicial engagement. $^{19}$

While dialogical approaches tend to focus on the role of courts, this article proposes that adjudication is only one aspect of cross-fertilization of trade and environmental issues. The discursive and dynamic aspects of adjudication can also find their way into the administrative function of the WTO. The workings of the Secretariat and its working groups and committees, allows the administrative parts of the WTO to become a political forum through which Member States may dialogue and reach agreement (or not) on matters concerning trade and the environment. ${ }^{20}$ Furthermore, committee decisions may in fact influence treaty interpretations of dispute settlement bodies, further impacting the ways in which trade and environmental issues may converge. ${ }^{21}$ This dual capacity of the WTO not only reinforces its institutional legitimacy with regard to nontrade areas impacting trade compliance, but also 'links' non-trade interests with trade. ${ }^{22}$

A dialogical lens also illuminates the role of fragmentation, through regional trade agreements such as the North American Free Trade Agreement (NAFTA) and El Mercado Común del Sur (MERCOSUR) for example, in 'linking' environmental issues to trade and development. In most cases,

17 See Teitel, above $\mathrm{n} 7$ at 2584-87; Waters, above $\mathrm{n} 7$ at 489-90.

18 See Ahdieh, above n 12, at 2049 (explaining that one characteristic of a dialogical approach is that it has 'bidirectionality'; and therefore, any court may initiate dialogue and engage with the jurisprudence of another).

19 Slaughter, 'A Typology of Transjudicial Communication', above n 14 (exploring the commonalities in the various horizontal and vertical forms of communication among courts transnationlly).

20 See Greg Shaffer, 'The World Trade Organization under Challenge: Democracy and the Law and Politics of the WTO's Treatment of Trade and Environmental Matters', 25 Harvard Environmental Law Review 1-93 (2001) (in applying three alternative frames of the WTO's handling of trade and environmental issues, the author discusses the 'intergovernmental perspective' as one that allows states to bargain in the WTO Committee on Trade and Environment and respond to various stakeholder interests).

21 See above Section IV.

22 See Jose Alvarez, 'The WTO as Linkage Machine', 96 American Journal of International Law 146 (2002). 
disputing parties tend to adjudicate trade and environment disputes at the multilateral level rather than the regional. ${ }^{23}$ This multi-level dynamic has also impacted the way in which trade and environmental issues have converged. Furthermore, global institutional frameworks are only one form of global governance. Soft law norms, through the workings of state and nonstate actors, contribute to the dynamism of modern global governance in which organic processes facilitate the furtherance of specific goals. ${ }^{24}$ The transnational processes arising from these relationships and law-making mechanisms form part of the relationship between trade and environmental concerns. Public and private partnerships involved in the development and implementation of regulatory policy bring new sets of issues to the trade and environment discourse.

Despite a broadening of the influence of trade norms into other legal domains like the environment, collision may arise among the application of rules in these various domains and among the normative goals that each is attempting to achieve. ${ }^{25}$ This article uses a dialogical approach not only to demonstrate the ways in which the relationship has evolved and transformed the WTOs jurisdictional scope to incorporate environmental concerns, but also to highlight that it is within the contestation of trade goals with those of environmental sustainability that new ways of thinking about the relationship may emerge, allowing for possible shifts in the normative objectives of either domain while considering the multilateral, regional, and domestic aspects. ${ }^{26}$

Section II of this article will provide an overview of the ways in which a dialogical approach to trade and environmental issues frames the relationship in a new way. Section III will look closely at the adjudicatory function of the General Agreement on Tariffs and Trade (GATT) and WTO panels and focus on provisions of the GATT itself most closely tied to environmental matters. Section IV of this article will consider the administrative capacity of

${ }^{23}$ See e.g. United States - Measures Concerning the Importation Marketing and Sale of Tuna and Tuna Products WT/CS381/R (Panel Report) (15 September 2011) (hereinafter US - Tuna Panel Report); United States - Measures Concerning the Importation Marketing and Sale of Tuna and Tuna Products WT/DS381/AB/R (Appellate Brief) (16 May 2012) (hereinafter US - Tuna II AB).

${ }^{24}$ David Kennedy, 'The Mystery of Global Governance', in Jeffrey L. Dunoff and Joel P. Trachtman (eds), Ruling the World? Constitutionalism, International Law, and Global Governance (2009), at 37, 40 (urging us to 'think about global governance as a dynamic process in which legal, political, and economic arrangements unleash interests, change the balance of forces, and lead to further reinvention of the governance scheme itself").

${ }^{25}$ See Gunther Teubner and Peter Korth, 'Two Kinds of Legal Pluralism: Collision of Transnational Regimes in the Double Fragmentation of World Society', in Margaret A. Young (ed.), Regime Interaction in International Law: Facing Fragmentation (Cambridge: Cambridge University Press, 2012).

${ }^{26}$ See Ibid at 29 (discussing that a collision of legal acts and norms characterizes 'post-modern interlegality' which does not give rise to 'a single "ultimate rule of recognition" and that '[n] either a hierarchical construction of the law nor a Grundnorm nor a common point of final reference can hold these heterachical systems together'). 
trade regimes, including those found in preferential trade agreements (PTAs), and considers the relationship of PTAs to the multilateral trade framework. Section V of this article discusses the dialogical impacts of fragmentation in trade governance; despite some convergence between trade and environment, there continues to be fragmentation. ${ }^{27}$ Finally, this article identifies how the dialogical dynamics of the adjudicatory and administrative functions of trade regimes have developed into a more robust discourse on the connections among trade, economic development, and environmental sustainability. 'Green' economic strategies, with the participation of both state and non-state actors, are the wave of the future, raising questions as to whether trade regimes can adapt to accommodate for environmental goods and services. The article concludes with reflections on the lessons that a dialogical approach to trade and the environment provides on better understanding the relationship today.

\section{A DIALOGICAL APPROACH}

A dialogical approach highlights the effects of transnationalism on trade. ${ }^{28} \mathrm{~A}$ dialogic theory has been applied to US constitutional law to understand the interactions between federal and state courts, and among the various branches of government. ${ }^{29}$ Despite its limitations, ${ }^{30}$ a dialogic approach highlights jurisdictional overlaps and emphasizes the interaction among

${ }^{27}$ But see, Joel P. Trachtman, 'Fragmentation and Coherence in International Law', (2011) draft available at http://ssrn.com/abstract $=1908862$.

28 See Harold Koh, 'Transnational Legal Process', 75 Nebraska Law Review 181 (1996), at 183-84 (discussing the nature of transnational legal processes as being at the core of international law and explaining that the 'transnational legal process describes the theory and practice of how public and private actors-nation-states, international organizations, multinational enterprise, non-governmental organizations, and private individuals - interact in a variety of public and private, domestic and international fora to make, interpret, enforce, and ultimately, internalize rules of transnational law').

29 See e.g. Tidmarsh, above n 9, at 1163 (stating that a dialogic theory 'contends, perhaps counterintuitively, that the fundamental constitutional role of each court system is to engage the other system in a dialogue about the extent and shape of the other system's rights, obligations, and entitlements'.). See also, Martin Redish, 'Supreme Court Review of State Court "Federal” Decisions: A Study in Interactive Federalism', 19 Georgia Law Review 861 (1985) (describing the 'interactive' aspects of federal and state courts as dialogic); and Barry Friedman, 'A Different Dialogue: The Supreme Court, Congress and Federal Jurisdiction', 85 Northwestern Law Review 1 (1990) (focusing on the value of dialogue among various branches of government).

30 See Tidmarsh, above $\mathrm{n}$ 9, at 1168-70 (explaining the limits of a dialogic theory as falling primarily into three categories: (i) the need for an ultimate arbiter of legal questions, (ii) efficiency based limitations focusing on the need for certain barriers to dialogue based on which courts should decide certain legal questions, and (iii) limits to dialogue based on constitutional concerns such as separation of powers and federalism). 
courts and branches of government, thereby revealing the use of multiple centers for legal-decision making. ${ }^{31}$

A dialogic approach has also been expanded into the comparative and transnational realms, where it animates the work of scholars who examine the interaction among national and foreign courts. ${ }^{32}$ It highlights that the various forms of 'transjudicial communication' can result in enhancing the effectiveness of supranational tribunals, promoting acceptance of reciprocal international obligations, enhancing cross-fertilization, and collective deliberation by courts on a common set of problems. ${ }^{33}$ Cross-fertilization refers to the 'dissemination of ideas from one national legal system to another, from one regional legal system to another, or from the international legal system or a particular regional legal system to national legal systems'. ${ }^{34}$ The fact that certain norms may cross jurisdictional barriers is very telling of the ways in which courts 'communicate', either directly or indirectly, with one another on issues of mutual concern.

Although this article is not intended to provide an overview nor an analysis of the dialogic theory, it finds the dialogic approach helpful in bringing new perspectives to the interplay of trade issues with those of the environment. While a dialogical approach is grounded in constitutionalism, this article uses this approach to provide important insights into the functionality of the WTOs adjudicatory and administrative capacities in linking trade to the environment. ${ }^{35}$ Though some scholars will argue that the WTO is not the correct forum to deal with nontrade issues such as the environment, ${ }^{36}$ this article does not make a normative claim in this regard one way or another. Instead, it takes a positivist approach, noting points where trade and environmental issues have already cross-fertilized and using the dialogic theory to illuminate the ways these important links have evolved over time.

A dialogic approach traditionally focuses on judicial 'dialogue'. ${ }^{37}$ In this article, however, the dialogical approach moves beyond the adjudicatory as a

${ }^{31}$ See ibid. See also, Alexandra D. Lahav, 'Recovering the Social Value of Jurisdictional Redundancy', 82 Tulane Law Review 2369 (2008), 2370-72 (discussing multi-centered litigation and concluding that 'jurisdictional redundancy', as first espoused by Robert $\mathrm{M}$. Cover, furthers the values of legal pluralism).

${ }^{32}$ See e.g. above nn $5,7,12-14$.

${ }^{33}$ See Slaughter, 'A Typology of Transjudicial Communication', above n 14, 17, at 114-22.

${ }^{34}$ Ibid at 117 .

${ }^{35}$ See Teitel, above $\mathrm{n} 7$.

${ }^{36}$ See Jeffrey L. Dunoff, 'The Death of the Trade Regime', 10 European Journal of International Law 733 (1999) (arguing that the political nature of linkage disputes makes them unfit for adjudication the WTO system); John H. Jackson, 'Dispute Settlement and WTO: Emerging Problems', 3 Journal of International Law 35 (1998) (finding that the WTO system may deal with some linkage issues but through the legal disciplines built into the WTO Covered Agreements). But see, Ernst-Ulrich Petersmann, 'Multi-level Trade Governance in the WTO Requires Multilevel Constitutionalism', in C. Joerges and E. U. Petersmann (eds), Constitutionalism, Multilevel Trade Governance and Social Regulation (2006), at 22 (arguing that the WTO system should be used to advance human rights).

${ }^{37}$ See Tidmarsh, above $\mathrm{n} 9$. 
means for dialogue. The administrative functions of the WTO also play an important role in not only reinforcing the adjudicatory, but also in initiating dialogue with nontrade stakeholders. This dual dynamic contributes in expanding the scope of trade institutions from a purely trade regulatory framework defined by its treaties and enforcement mechanisms.

This article focuses on three dialogical aspects to the trade and environment dichotomy. First, the internal legal frameworks of the WTO, supported by the GATT and Covered Agreements, provide a space under which the adjudicatory processes of the WTO may consider trade and nontrade matters, including specifically issues concerning environmental regulation. WTO jurisprudence, arising from its adjudicatory function has impacted environmental regulation over time. Furthermore, judicial discretion, through treaty interpretation by WTO panelists and judges, plays a key role in the development of this jurisprudence, also impacting the way that environmental concerns cross fertilize into the trade regime.

Second, the administrative capacity of the WTO, through its Secretariat and Committees, fosters enhanced dialogue between trade and environmental stakeholders. The 1994 mandate for the WTO Committee on Trade and Environment (CTE), for example, was to identify the relationship between trade measures and environmental ones to promote sustainable development and to make recommendations in this regard. The 2001 Doha Declaration asked the CTE to work on specific areas concerning trade and environment; including, 'green protectionism', relevant TRIPS provisions, labeling requirements, and special rules for environmental goods and services. Furthermore, in light of the current impasse on the Doha Round, the Secretariat has found other means of bringing trade and nontrade stakeholders together to discuss matters of common interest.

Third, a dialogical approach provides a prism through which to see fragmentation in the trade system and ways that this has contributed to the cross fertilization of trade and environmental issues. As trade policy has expanded among nations, the multiplicity of jurisdictional regimes in the trading system itself has provided for various opportunities for dialogue among free traders and environmentalists, either through the adjudicatory processes in those regional and bilateral arrangements, or through the negotiations and working groups under those agreements dealing with these matters. Furthermore, as a result of increasing fragmentation, trade regimes continually interact with nontrade regimes, also contributing to cross fertilization. These points of intersection have varying degrees of impact, from formal forms of cross fertilization, where treaties recognize the trade and environment relationship (such as regional trade agreements) to less tangible forms of convergence where different adjudicatory fora may have jurisdiction over the same dispute (like Chile-Swordfish). In addition, fragmentation provides room for less formal means of cross fertilization, where transnational 
regulatory norms emerge and 'greening the economy' becomes the currency for sustainable policies. ${ }^{38}$ In this context, the institutional framework of the WTO may become a focal point for various public and private actors to discuss and establish transnational norms that impact environmental issues and trade ones.

\section{ADJUDICATORY CAPACITY OF THE WTO}

The internal adjudicatory framework of the multilateral trade regime has allowed for a judicial 'dialogue' between the interests of the environmental and trade communities, where domestic environmental regulations have collided with trade compliance. This interaction first occurred under the provisions of the GATT itself. The interplay between Articles III and XX for example provides adjudicatory panels with a legal framework upon which to deal with environmental measures that may be legitimate either because they pass the muster of national treatment requirements under Article III or because they form an exception under Article XX. ${ }^{39}$ Article XX can be invoked as a defense to alleged violations of Article III as long as the measures are not applied 'as a means of arbitrary or unjustifiable discrimination'. ${ }^{40}$ Furthermore, WTO panels established relevant jurisprudence on interpreting these provisions in the context domestic environmental regulations and with respect to issues related to the environmental effects of the life cycle of a product, known as Product Production Methods (PPMs). These types of internal dialogical interfaces have occurred within the single treaty of the GATT.

After 1994, the multilateral trade legal framework incorporated new agreements beyond the GATT to constitute the WTO Covered Agreements. ${ }^{41}$ Among those included were two that specifically dealt with regulations concerning health and safety of a state's population, animals, and environment; namely, the Technical Barriers to Trade (TBT) and the Sanitary and Phytosanitary Agreements (SPS). ${ }^{42}$ These agreements provide for domestic regulatory agencies to conduct domestic risk assessment to determine the

${ }^{38}$ See below Section VI.

${ }^{39}$ Robert Hudec, GATT/WTO 'Constraints on National Regulation: Requiem for an 'Aims and Effects' Test', The International Lawyer 32 (1998), at 619-49.

${ }^{40}$ GATT Article XX, Chapeau.

${ }^{41}$ See generally Understanding on Rules and Procedures Governing the Settlement of Disputes, 15 April 1994, Marrakesh Agreement Establishing the World Trade Organization, Annex 2, Legal Instruments-Results of the Uruguay Round, app. 1, 33 I.L.M. 1125 (1994).

${ }^{42}$ See Final Act Embodying the Results of the Uruguay Round of Multilateral Trade Negotiations, Technical Barriers to Trade Agreement, 15 Aprril 1994, WTO Agreement, Annex 1A (hereinafter, TBT Agreement), and. Final Act Embodying the Results of the Uruguay Round of Multilateral Trade Negotiations, Sanitary and Phytosanitary Measures Agreement, 15 April 1994, WTO Agreement, Annex 1A (hereinafter, SPS agreement). 
necessity of certain regulatory measures as compared to the costs on free trade. The TBT and the SPS Agreements both give heightened legitimacy to regulations in compliance with international standards, but do not define clearly what international standards may pass muster or what constitutes a recognized 'international standardizing body'. 43

In the establishment of these agreements, WTO panels are capable of taking a more formal adjudicatory approach in dealing with nontariff barriers while recognizing the sovereign right of Member States to implement domestic regulatory policy. Furthermore, WTO panels have been 'ruleoriented', abiding by the interpretation principles of the Vienna Convention and being cautious about looking beyond the Covered Agreements to interpret the GATT. ${ }^{44}$ These 'formal' approaches within the confines of WTO adjudication have contributed to the legitimacy of the WTO and its governing for matters of trade regulation.

\section{A. Early trade and environment cases and their effects on US environmental regulation}

\section{US-Tuna I}

With United States-Restrictions on Imports of Tuna, the tension between environmentalists and free trader began to take hold. ${ }^{45}$ In US-Tuna I, Mexico alleged that a US moratorium on imports of Mexican yellowfin tuna through the implementation of the US Marine Mammal Protection Act violated general prohibition of quantitative restrictions under Article XI of the GATT and nondiscriminatory administration of quantitative restrictions under Article XIII. ${ }^{46}$ Furthermore, it claimed national treatment violations under Article III of the GATT. ${ }^{47}$ The USA responded asserting that Article XI and XIII were inapplicable and that the direct embargo was not in violation of Article III; however, if found in violation, it was in fact

${ }^{43}$ See TBT Agreement, Articles 2.2, 2.4, 2.5. See also SPS Agreement Articles 3.1, 3.2. In US - Tuna II, the Appellate Body attempted to provide guidance to the meaning of 'international standards'. See United States-Measures Concerning the Importation Marketing and Sale of Tuna and Tuna Products WT/DS381/AB/R (Appellate Brief) (16 May 2012) (hereinafter US - Tuna II $\mathrm{AB})$.

${ }^{44}$ See John H. Jackson, The World Trading System (1997), Ch. 4. See also, Petros C. Mavroidis, 'No Outsourcing of Law? WTO Law as Practiced by WTO Courts', 102 American Journal of International Law 421 (2008) (distinguishing between 'sources of WTO law', which are those international agreements explicitly referred to within the texts of WTO agreements as well as customary international law, and 'interpretive elements'.).

45 United States - Restrictions on Imports of Tuna, GATT Doc. DS21/R (3 September 1991). 30 O.L.M. 1594 (1991) (unadopted panel report) (hereinafter called, US - Tuna I).

${ }^{46}$ See Ibid, para 3, 3.11. Among other arguments, Mexico also claimed that the US Dolphin Protection Consumer Information Act violated Articles IX and I of the GATT. See Ibid at para 3.

47 Marine Mammal Protection Act of 1972, 16 U.S.C. $\S 1361$, s 101 (Hereinafter MMPA). The MMPA essentially prohibited all importation of tuna unless the exporting country proved that the tuna was caught according to standards in the MMPA. 
allowed under Article XX (b) and (g). ${ }^{48}$ The USA argued it was allowed to pass such a law because it was 'necessary' in order to protect 'human, animal or plant life or health' and because it was related to the 'conservation of exhaustible natural resources'. ${ }^{49}$ In addition to claiming that the US law was not regulating process and production methods, ${ }^{50}$ Mexico argued that a proposal to include the 'conservation of fisheries resources, migratory birds or wild animals' during the preparatory work of the Havana Charter was specifically excluded; and therefore, that such environmental issues should not be part of the general exceptions under Article XX. ${ }^{51}$ Furthermore, the USA referred to the Convention on International Trade in Endangered Species of Wild Fauna and Flora (CITES) in defending its position that it could prohibit the importation of products in order to protect endangered species. ${ }^{52}$

The GATT panel shocked many environmental groups with its decision finding that, if Article III of GATT applied, the US measure would in fact be violation of GATT Article III. However, the Panel explained that since the measure related to the process of capturing tuna and not the final product itself, in this case tuna, that GATT Article III was not applicable. ${ }^{53}$ Furthermore, the GATT panel found that the US moratorium was beyond the reach of US jurisdiction and therefore, did not qualify for any of the GATT Article XX exceptions. ${ }^{54}$ This case was significant for the trade and environment relationship, though, in various ways. It was the first trade case to assess the legality under trade law of a domestic environmental regulation, setting the tone for future adjudication of environmental regulations impacting trade. Furthermore, the adjudicatory process allowed the Parties to attempt to incorporate a multilateral environmental agreement into their claims, even if only to fortify their respective legal arguments though the Panel did not address its relevance in this case.

48 See US - Tuna I, above n 45, paras 3.6, 3.14. The USA argued that the intermediary nation embargo was justified under Article XX (b), (d), and (g). See Ibid para 3.7.

49 See Ibid,para 5.8 .

${ }^{50} \mathrm{Ibid}$, at para 3.17. The USA argued that in fact the MMPA was a regulation for process and production methods. See Ibid, at para 3.18 .

51 Ibid, at para 3.30 (referring to the United Nations Conference on Trade and Employment, Reports of the Committees and Principle Subcommittees, ICITO/8, ('Havana Reports'), pp. 84-85, paras 18,21). The US disagreed and referred to previous panels finding fishery resources to be exhaustible natural resources. See Ibid paras 3.30, 3.40.

52 See Ibid para 3.36. Mexico noted that CITES did not list the dolphins that MMPA was intending to protect. See Ibid, at para 3.44. Convention on International Trade on Endangered Species of Wild Fauna and Flora (CITES), 993 U.N.T.S. 243 (1 July 1975).

53 See Ibid, paras 5.10-5.15. The Panel found that Note Ad Article III was not applicable, but did establish a violation of Article XI. See Ibid para 5.19.

54 See Ibid, paras 5.26-5.34. The Panel also found no justification for the intermediary nations embargo under Article XX(d). See Ibid paras 5.39-5.40. 
In 1994, the European Community and the Netherlands brought another similar complaint challenging MMPA. ${ }^{55}$ This time the emphasis was on the secondary embargo on nations importing tuna from a state directly under the US embargo of tuna imports. ${ }^{56}$ The GATT panel came to a similar conclusion as in the first US-Tuna I, with an important distinction. It found that regulatory measures for the protection of human, animal, or plant life could be valid under Article $\mathrm{XX}(\mathrm{b})$ even if these measures were not confined to the jurisdictional boundaries of the state implementing the regulation. ${ }^{57}$ That is, PPMs could be legitimate under the GATT but the Panel did not provide much guidance as to under what circumstances. In this case, though, the Panel narrowly interpreted Article $\mathrm{XX}(\mathrm{b})$ finding that the domestic regulatory measure in question was not 'necessary' under Article XX(b) but recognized that nations had the right to regulate their own exhaustible natural resources. ${ }^{58}$

In essence, though, this case solidified the decision in Tuna-Dolphin I and gave little hope to environmentalists that the tension between trade and the environment could be alleviated. However, it did lead to adjustments in US law concerning tuna fishing and to multilateral negotiations among the parties involved. Soon after, the USA and Mexico entered into the 1999 Agreement on the International Dolphin Conservation Program (AIDCP). ${ }^{59}$ Herein lies the dialogical aspect of the trade-environment interface produced by these early cases. First, the non-trade issue of an environmental regulation had to be addressed within the confines of the GATT treaty, and in this way, crossfertilization began to take hold through the process of judicial review. ${ }^{60}$ Second, the adjudicatory force of these GATT decisions (and later ones) led to domestic regulatory adjustments so as to bring violating Member States into compliance with trade commitments. As in US-Tuna I, the decision in US-Standards for Reformulated and Conventional Gasoline where a WTO appellate body found a 1990 US amendment to the Clean Air Act establishing a baseline for allowable vehicle fuel emissions to be a disguised restriction on trade, the USA signed a new 1997 regulation to comply with the WTO decision. ${ }^{61}$ Third, the adjudicatory response also initiated other opportunities for

55 See United States Restrictions on Imports of Tuna, GATT Doc. DS29/R (16 January 1994), 33 I.L.M. 839 (1994) (hereinafter US - Tuna Ia) (unadopted panel report).

${ }^{56}$ See Ibid, at paras $2.12-2.15$; 3.1. See also, MMPA, 16 U.S.C. $§ 1371$ (a)(2)(C) (creating an indirect embargo on nations that could not prove that tuna imports as far back as six months did not originally come from a nation directly subject to the US embargo).

${ }^{57}$ See Tuna - Dolphin Ia, paras 5.28-5.39.

${ }^{58}$ See Ibid paras 5.26-5.38.

59 See Trujillo, 'The Tuna-Dolphin Encore', ASIL-Insights March 2012 (discussing the formation of the AIDCP).

${ }^{60}$ See Ruti Teitel, 'Comparative Constitutional Law in a Global Age', 117 Harvard Law Review 2570 (2004), at 2584-87 (stating that 'this view of a contemporary transnational constitutional regime offers an alternative basis from which to justify comparativism that is grounded in the processes of judicial review'.).

${ }^{61}$ US - Standards for Reformulated and Conventional Gasoline, AB Report, WT/DS2/AB/R May 1996 (hereinafter called US - Gasoline). 
convergence with respect to trade and environmental issues; namely, multilateral cooperation to address environmental and sustainability concerns. ${ }^{62}$

Soon after the US-Tuna cases, the 1992 Rio Declaration on Environment and Development came into existence, ${ }^{63}$ which, among other things, incorporated the concerns of trade with those of the environment. Its force was in the international discourse on the environment that followed; namely, the Declaration on the Environment and Development, the Conventions on Biodiversity and Climate Change and the 'Agenda 21', discussing methods for sustainable development. Principle 15 of the Rio Declaration encourages the use of precautionary approach and discourages the use of scientific certainty as justification for allowing environmental harms. ${ }^{64}$ Even if not a legally binding international treaty, the Rio Declaration attempted to address trade concerns in the context of sustainable development by setting a new international tone around the important linkages among trade, development, and sustainability.

\section{Shrimp - Turtle}

In 1998, India, Pakistan, Malaysia, and Thailand initiated a WTO complaint alleging that the US regulation requiring that all shrimpers, foreign and domestic, exporting shrimp to the USA use a 'turtle excluder device' (TED) according to US agency standards. The concern was that the purse-seine nets used to fish shrimp would accidentally catch sea turtles, an endangered species both under the CITES and the US Endangered Species Act of 1973. ${ }^{65}$ The USA had begun international agreements with other nations to protect the turtles. However, India, Pakistan, Malaysia, and Thailand had not entered into such an agreement with the USA. ${ }^{66}$

The WTO panel found the USA restriction to be a violation of GATT 1994 Article XI:1 violation and not justifiable under Article XX. ${ }^{67}$ The Panel decision focused on whether the domestic regulatory measure may affect the multilateral system in significant ways, particularly with respect to market access. ${ }^{68}$ The USA appealed and the Appellate Body, though

${ }^{62}$ See Teitel, above n 7 (stating that a dialogical approach may offer the possibility of crossfertilization and convergence, enhancing 'global solidarity' on certain issues like human rights).

${ }^{63}$ Rio Declaration on Environment and Development, 21 I.L. M. 874.

64 See Ibid, Principle 15.

${ }^{65}$ US Endangered Species Act of 1973, 16 U.S.C. $§ 1531$ et. seq. (1973). See United States Import Prohibition of Certain Shrimp and Shrimp Products, WT DS58/AB/R, 12 October 1998; 38 I.L.M. 118 (1999) (hereinafter, Shrimp - Turtle AB Report), paras 3-6.

${ }^{66}$ See generally, Lowenfeld, International Economic Law, 2nd ed. (Oxford: Oxford University Press, 2008), at 319-20.

${ }^{67}$ See United States - Import Prohibition of Certain Shrimp and Shrimp Products, WT/DS58/R15 May 1998, 37 I.L.M. 832 (1998) (hereinafter, Shrimp - Turtle Panel Report), paras 8.1-8.2.

68 Shrimp - Turtle Panel Report, para 7.51. See generally, Rob Howse, 'The Appellate Body Rulings in the Shrimp/Turtle Case: A New Legal Baseline for the Trade and Environment Debate', 27 Columbia Journal of International Law 491 (2002). 
agreeing that there was a violation, provided a small glimpse of hope for environmentalists in finding that section 609 was indeed within the scope of Article XX. ${ }^{69}$ The Appellate Body emphasized that in adjudicating a domestic environmental regulation, it was important for panels to consider the manner in which the violation is applied. ${ }^{70}$ It recognized that nations had the sovereign right to regulate the environment; however, it faulted the USA for having done so unilaterally and without pursuing a multilateral forum. ${ }^{71}$ However, it also clarified that unlike the Panel's conclusion, the legal analysis under Article XX does not require a look into whether a domestic regulation undermines the multilateral trading system; rather, the crucial issue is whether it poses an 'unjustifiable discrimination between countries'. ${ }^{72}$ The Appellate Body determined this measure as unjustifiable and arbitrary under the chapeau of Article XX, the gatekeeper for possible Article XX exceptions. ${ }^{73}$ Without imposing a duty on nations to negotiate multilaterally, the Appellate Body once again brought domestic environmental regulations within its jurisdictional domain, and was cautious of unilateral solutions, while encouraging negotiated solutions.

Unlike the US-Tuna Reports, Shrimp-Turtle was decided under the WTO dispute settlement body and the panel and Appellate Body reports were adopted. However, like US-Tuna I, in Shrimp-Turtle, the USA cited a multilateral environmental agreement, CITES, to provide strength to its argument that in fact section 609 was compliant because it protected an endangered species as noted in this international environmental agreement. ${ }^{74}$ The Appellate Body also referred to environmental treaties and resolutions such as UNCLOS and Agenda 21 and considered the Resolution on Assistance to Developing Countries. ${ }^{75}$ Though the WTO still has not clarified the relationship of multilateral environmental agreements (MEAs) or international resolutions to the WTO Covered Agreements or to the trade regime, these strategic legal arguments on the part of the Parties and the willingness of the WTO dispute settlement bodies (DSB) to entertain these arguments highlights the dialogical qualities of the adjudicatory capacity of the WTO when it comes to trade and the environment. This has contributed enhanced crossfertilization between the two camps.

Furthermore, Shrimp-Turtle also recognized that exhaustible resources under Article $\mathrm{XX}(\mathrm{g})$ are not limited to non-living natural resources; that

\footnotetext{
69 Shrimp - Turtle AB Report, para 10.

${ }^{70}$ Ibid, para 115.

71 See Howse, above n 68.

72 Shrimp - Turtle AB Report, above n 65 paras 12-13; 15; 116.

73 Article XX. Shrimp - Turtle AB Report, above n 65 paras 158-60.

74 Shrimp - Turtle, above n 65 para 25. The USA argued that "Section 609 "relates to" the conservation of sea turtles' and therefore is justified under Article XX(g). See Ibid at para 26.

75 Ibid, at para 130.
} 
" "exhaustible" and "renewable" natural resources are [not] mutually exclusive and that they are "suspectible of depletion, exhaustion and extinction, frequently because of human activities", 76 This recognition further highlights the role of the WTO adjudicatory process in cross-fertilizing trade regulation with that of the preservation of natural resources.

Though disturbing to environmentalists, ${ }^{77}$ these early environment and trade disputes allowed the DSB to better identify the role of Article XX with respect to the trade and environment relationship. Though not fully understood at the time, Shrimp-Turtle changed the way Appellate Bodies would deal with the compliance of environmental measures to the trade regime, recognizing that trade treaty interpretations had to be in light of environmental concerns. ${ }^{78}$

\section{B. Role of judicial discretion}

The early environmental cases demonstrated the ability of DSB panels to exercise judicial discretion not only in narrowing or expanding the scope of provisions in the GATT, but also in choosing to use judicial economy to not adjudicate under certain provisions or to ignore outside sources of international environmental law such as MEAs and the Rio Declaration. These are also pinnacle moments for the convergence of trade and environmental issues, highlighting the important role of the adjudicatory. ${ }^{79}$ Furthermore, in this cross-fertilization trade panels may choose to incorporate domestic environmental and other regulations into the legal framework of trade and to interpret the trade treaties in ways that recognize the legitimacy of some domestic regulations. EC-Asbestos, for example, illustrated the willingness of the WTO DSB to broaden GATT Article III to accommodate for categories of 'like products' that could include legitimate regulatory measures. ${ }^{80}$ When addressing environmental concerns, the way trade deals with relevant legal concepts such as process and production methods and the precautionary principle becomes increasingly important.

${ }^{76}$ US - Shrimp, above n 65 para 128.

77 See Howse, above n 68, at 494.

78 See US - Shrimp, above n 65 para 129.

79 See John Knox, 'The Judicial Resolution of Conflicts Between Trade and the Environment', 28 Harvard Environmental Law Review 1 (2004) (discussing that the Appellate Body's role in 'greening ... trade jurisprudence' is primarily motivated by political concerns).

80 See European Communities - Measures Affecting Asbestos and Asbestos Containing Products, WT/ DS135/AB/R (12 March 2001) (hereinafter EC - Asbestos) para 99. For more discussion on the way in which the AB contextualized Article III for distinguishing between products with and without chrysotile asbestos fibers, see Elizabeth Trujillo, 'Mission Possible: Reciprocal Deference Between Domestic Regulatory Structures and the WTO', 40 Cornell International Law Journal 201 (2007), at 221, 225. 


\section{PPMs}

Traditionally, trade dispute settlement bodies have been hesitant to allow regulations designed to regulate process and production methods as seen in the first two Tuna-Dolphin reports. The primary goal of the multilateral trade regime has been to provide market access to products and reduce tariff and non-tariff barriers. In doing so, the language of the GATT treaty as well as other related Covered Agreements focus on the products themselves, rather than on processes that go into making of the product. This is not to say, though, that the WTO agreements discard entirely the notion of process. There has been much debate about PPMs. ${ }^{81}$ Shrimp-Turtle clearly opened the door for the possibility of PPMs to be within the scope of Article XX exceptions. ${ }^{82}$

One WTO case that exemplifies some of these issues in the context of the SPS Agreement is European Communities - Measures Affecting the Approval and Marketing of Biotech Products, dealing with European restrictions on the importation of genetically modified organisms (GMOs). ${ }^{83}$ The European Union (EU) passed regulations for requiring labels for foods that contained GMOs. Argentina, the USA, and Canada brought this issue before the WTO alleging these requirements to be violations of the GATT and the SPS Agreement. ${ }^{84}$ The WTO panel ruled in favor of the complainants in this case. With respect to the process-product distinction, the WTO agreed with the argument that the emphasis for WTO adjudication of these measures should be on the final product rather than on the process, especially when the end-product is 'substantially equivalent' to the product at the beginning of production. ${ }^{85}$ The panel found the EU measures inconsistent with the SPS Agreement because they were not based on risk assessments and unsubstantiated by scientific evidence. It also found that these labels were not in compliance with GATT and that the EU measure amounted to a moratorium between 1999 and 2003 on approval of biotech products, providing

81 See Christiane R. Conrad, Processes and Production Methods (PPMs) in WTO Law: Interfacing trade and social goals (2011), at 20-31. For more on the development of process-product legal doctrine, see generally Robert Hudec, 'The Process-Product Doctrine in GATT/WTO Jurisprudence', in Bronkers and Quick (eds), New Directions, (2000), 187-217.

82 US - Shrimp Appellate Report, paras 10, 12, 115-123. See also Doug Kysar, 'Preferences for Processes: The Process/Product Distinction and the Regulation of Consumer Choice' 118 Harvard Law Review 525 (2004).

83 European Communities - Measures Affecting the Approval and Marketing of Biotech Products, WT/ DS291,292,293/INTERIM (hereinafter ' $E C$ - Biotech Products').

${ }^{84}$ See Ibid. See also SPS agreement above n 42.

${ }^{85} E U$ - Biotech Products, above n 83. In EC-Hormones, the WTO sided with the USA in stating that non-product related PPM's should not be a distinguishing factor between meat products with or without hormones because they are the 'substantial equivalent' of each other and it does not change the final product. Report of the Appellate Body on European CommunitiesMeasures Affecting Meat and Meat Products (Hormones), WTO Doc. WTIDS26/ABIR (16 January 1998). 
'undue delays' in the EU approval process in violation of Article 8 of the SPS Agreement. ${ }^{86}$

Though the ultimate outcome of this case was based on a procedural issue regarding risk assessment, EC-Biotech Products has several dialogical effects where the WTO panel engaged with non-trade legal domains concerning the environment. First, the Panel received three unsolicited amicus curiae briefs and the parties. ${ }^{87}$ Non-party amicus curiae briefs is one way that convergence is taking place, for it allows non-state actors, such as NGO's and private entities, to penetrate the trade framework. ${ }^{88}$

Second, the Panel in EC-Biotech allowed parties the opportunity to seek advice from scientific and technical experts and decided that certain categories of issues required expert advice, in particular with respect to standards for risk assessment for each biotech product in question. ${ }^{89}$ Third, the Panel addressed the relevance of rules of international law outside of trade; namely, the Convention on Biological Diversity, the Biosafety Protocol, and the precautionary principle. ${ }^{90}$ It ultimately concluded that because one of the four parties had not ratified the latter two multilateral environmental agreements, they would not be applicable to this case, according to its interpretation of Article 31(3)(c).$^{91}$ With respect to the precautionary principle, the Panel decided to follow precedent and not apply it '[s]ince the legal status of the precautionary principle remains unsettled' as a matter of international law. ${ }^{92}$

Finally, out of the initial dispute around bio-tech products came dialogue. The EU and Argentina subsequently entered into negotiations as to the timeframe in which the EU would adjust its measures to comport with the WTO decision. After postponing this timeframe several times, in March 2010, Argentina and the EU notified the WTO that they had agreed to establish bilateral dialogue on issues related to biotechnology and agriculture. ${ }^{93}$ The EU and the USA have not reached an agreement on the issue, though ongoing dialogue continues. ${ }^{94}$ The source of the debate lies in part,

${ }^{86}$ EU - Biotech Products, above n 83.

87 See e.g. Ibid, paras 7.10-11.

${ }^{88}$ See US -Tuna II Panel Report, above n 23 paras 7.1-7.9; 7.182-7.183; 7.288, 7.363 where the Panel addressed issues raised in the Written Submission of Non-Party Amici Curiae, Humane Society International American University, Washington College of Law, Program on International and Comparative Environmental Law, WT/DS381, 6 May 2010. In the Glamis Gold NAFTA case, amicus curiae briefs were also submitted and accepted by the NAFTA investor-state tribunal.

${ }^{89}$ See Ibid, paras 7.31-32.

90 See Ibid, paras 7.51-54.

91 See paras paras 7.74-75. The USA has not ratified the Convention on Biological Diversity and not signed the Biosafety Protocol.

92 See EU - Biotech Products paras 7.87-89. See also EC - Hormones paras 123-24.

93 http://www.wto.org/english/tratop_e/dispu_e/cases_e/ds293_e.htm. The EU and Canada have also reached a similar agreement, see http://europa.eu/rapid/press-release_IP-09-1142_en.htm.

${ }^{94}$ See Charles E. Hanrahan, 'Agricultural Biotechnology: The U.S.-EU Dispute', CRS Report for Congress (8 April 2010), available at www.crs.gov. 
in the different regulatory schemes between the USA and the EU. The US regulation of GMO products does not regulate those products that are substantially equivalent to those without GMOs. The EU, on the other hand, is less willing to accept GMO products and after 2004, labeling has been focused on informing consumers of GMOs in products for consumption by taking a precautionary approach. ${ }^{95}$

The issue of PPMs is at the heart of many environmental regulations, especially those concerning climate change initiatives. It is perhaps one of the most controversial issues for the WTO. Product labeling and traceability issues regarding the products have also moved to the center of the debate, issues that more recent cases like the US - Tuna II case highlight. Resolving the relationship between PPMs and trade is particularly important when developing climate change policies, since strategies incentivizing 'cleaner' more energy efficient products are not necessarily directed to the final product itself, but to the way a product is manufactured or obtained. ${ }^{96}$ However, because of the difficulty in finding a multilateral solution regarding PPMs, the judicial discretion of the WTO DSB takes on a heightened role. As is shown in US-Tuna II, it can adjudicate PPMs and bring them within the scope of trade jurisprudence without explicitly ruling on their relevance or legitimacy, except on a case by case basis.

\section{US-Tuna II}

The 2012 US-Tuna II case provides an example of judicial discretion as applied to a technical regulation regarding environmental labeling. In this case, Mexico claimed that the US dolphin-safe labeling scheme under the US Dolphin Protection Consumer Information Act and related regulations and rulings violated the GATT and TBT because it was a discriminatory 'technical regulation' that was more trade-restrictive than necessary, unjustifiably failing to use an international standard as its basis. ${ }^{97}$ The labeling scheme, intended to protect dolphins from purse-seine fishing nets and inform consumers, was not required for tuna imports, but if applied, contained specific requirements enforceable under the US law. The regulation required a certification that (i) no tuna was caught in the Eastern Tropical Pacific Region (ETP), impacting Mexican tuna, (ii) no tuna was caught by 'setting on' dolphins, and (iii) 'no dolphins were killed or seriously injured'. ${ }^{98}$

95 See Daniel W. Dresner, All Politics is Global: Explaining International Regulatory Regimes, (Princeton University Press, 2007), 149-175.

96 Towards Green Growth, pp. 36-38; 46-50, 2011, available at http://www.oecd.org/ greengrowth/48224539.pdf.

97 See Trujillo, The Tuna-Dolphin Encore, above n 59. Mexico claimed that the USA labeling scheme violated TBT Articles 2.1, 2.2, and 2.4 as well as GATT Articles I:1 and III:4. See also, Dolphin Protection Consumer Information Act, 16 U.S.C. $§ 1385$ (1990) [DPCIA]; 50 C.F.R. 216.91-92; Earth Island Institute v Hogarth, 484 F.3d 1123 (9th Cir.2007), amended by 494 F.3d 757 (9th Cir. 2007).

98 US - Tuna II Panel Report, above n 23, paras 2.3-2.16. 
The USA claimed and provided evidence that dolphins were more at risk in the ETP than outside of it due to the prevalence of purse-seine fishing methods.

One of the legal issues raised in this case was whether the US dolphin-safe label was a 'technical regulation' under Article 2.1 of the TBT Agreement, which would make the label a mandatory government label. The Panel spent some time finding that in fact it was mandatory because the regulation 'prescribe[d] and impose[d] the conditions under which a product may be labelled dolphin-safe', though the label itself was not required by the US government in order to sell tuna products. ${ }^{99}$ The Panel's decision seems to imply that virtually any state action may in fact turn a labeling scheme into a mandatory technical regulation. The Appellate Body, in addressing the US's appeal of this issue, agreed that this measure was a technical regulation since it set out legally mandated set of requirements to obtain the dolphin-safe label and specific enforcement mechanisms. ${ }^{100}$ In doing so, the Appellate Body implied that any regulation, including one that regulated the process and production method, with government oversight and enforcement would be deemed mandatory for purposes of the TBT Agreement; and therefore, could come within the scope of a 'technical regulation'. In this way, judicial discretion by the Appellate Body further enhanced cross-fertilization of trade and environmental issues, bringing not only a PPM but a non-product related PPM within the jurisdictional scope of a trade agreement. Other dialogical effects include (i) the Panel's and AB's recognition of the legitimacy of the environmental agreement, AIDCP, and its relevance to the facts in this case, even if it was found not to be a relevant standardizing body by the Appellate Body, and (ii) the willingness of the Panel to admit a non-party amicus brief and refer to it in its decision. ${ }^{101}$ Recently, the USA adjusted its dolphin-safe labeling scheme to comply with the WTO decision; however, the Mexican government has issued a statement that the two-tiered US regulatory scheme still discriminates against Mexican tuna imports and does not comply with the WTO decision. ${ }^{102}$ In this way, US-Tuna II provides another dialogical effect: that of the domestic regulatory response concerning environmental protection to trade adjudication.

${ }^{99}$ Ibid, para 7.131. The minority dissent did not agree with the majority opinion that the USA labeling scheme was mandatory; and therefore, a technical regulation.

${ }^{100}$ US-Tuna II AB Report, above n 23, paras 193-94.

${ }^{101}$ Mexico's Responses to the Panel's Questions From the Second Substantive Meeting, DS381, para 88 (19 January 2010). See also, Comments of the USA on the Answers of Mexico to the Second Set of Questions from the Panel to the Parties, DS381, para 10 (26 January 2011).

102 See US Federal Register, Rules and Regulation, Vol. 78, July 9, 2013, Enhanced Document Requirements to Support Use of the Dolphin Safe Label on Tuna Products. But also see Mexican response from the Mexican Ministry of Agriculture, México impugnará ante la OMC la nueva regulación de Estados Unidos sobre etiquetado 'dolphin safe', available at http://www.sagarpa.gob. $\mathrm{mx} /$ saladeprensa/2012/Paginas/2013B392.aspx. 
The Panel called for judicial economy and dealt with the issue solely under the TBT Agreement. ${ }^{103}$ The Appellate Body agreed with Mexico's appeal that the panel acted 'inconsistently with Article 11 of the DSU in deciding to exercise judicial economy' regarding claims of GATT violations. ${ }^{104}$ However, the Appellate Body ultimately did not decide these claims. This interesting dance between the relevant GATT provisions and the TBT Agreements, without clarification as to their relationship, allows the WTO DSB freedom to expand on its reasoning for allowing or disallowing certain regulatory measures. This judicial discretion, while arguably providing for more flexibility regarding trade and domestic regulation, also increases uncertainty with respect to how trade panels will deal with regulatory measures more generally and environmental ones more specifically.

\section{China and raw materials}

Finally, in a very recent controversy involving Chinese exportation of raw materials, the WTO panel and Appellate Body have made important strides in interpreting the scope of GATT Article XI (quantitative restrictions) exceptions and of Article XX. ${ }^{105}$ China created a system of export restrictions and quotas for nine of its raw materials, many of which are only available in China. These restrictions affected supply chains and increased export prices. China defended its position against the complainants, which included the USA, the EU, and Mexico, by claiming that the restrictions were justified because of 'critical shortages', an exception under Article XI of the GATT regarding the elimination of quantitative restrictions. The Appellate Body agreed with the Panel in rejecting this justification.

This was the first time the WTO addressed this issue of critical shortages on essential raw materials, an issue of particular importance to industrialized countries where a developing country holds such a monopoly on rich natural resources. ${ }^{106}$ Furthermore, the WTO for the first time had to address the applicability of Article XX to China's obligations under paragraph 11.3 of China's accession protocol. The WTO panel and Appellate Body found that Article XX did not apply to the accession protocol. ${ }^{107}$ As in US-Tuna II and other cases, the WTO did not provide clarification to the question of whether Article XX may justify violations to other WTO Covered Agreements, a 'fall-back option'. ${ }^{108}$ The relationship between the GATT and other Covered Agreements remains unclear, but in leaving it unclear, the WTO dispute settlement bodies allow themselves discretion on how to

${ }^{103}$ US - Tuna II Panel Report, above n 23, para 7.748.

${ }^{104}$ See Mexico's appellant submission at paras 206 \& 211, and US-Tuna II AB Report above n 23 at paras $405-406$.

105 China - Measures Related to the Exportation of Various Raw Materials, WT/DS394,395,398/

$\mathrm{AB} / \mathrm{R}$ (22 February 2012) (hereinafter China - Raw Materials).

${ }^{106}$ See ICTSD Bridges Weekly Trade News Digest, vol. 16, no. 4, February 2012.

${ }^{107}$ See Ibid. See also, China - Raw Materials, above n 104.

${ }^{108}$ ICTSD Bridges Weekly Trade News Digest, vol. 16, no. 4, February 2012. 
interpret these provisions and in deciding which agreements are the most applicable in any given case. However, the Appellate Body also used its judicial discretion to 'harden' the bargained-for provisions of the Accession Protocol into its interpretation of relevant GATT provisions. This case illustrates the way in which the administrative and adjudicatory functions of the WTO may reinforce one another.

Most recently, the USA, the EU, and Japan have initiated another dispute regarding Chinese export restrictions on rare earths. ${ }^{109}$ China produces $97 \%$ of the world production of rare earths which are used for many clean energy products such as wind power turbines, energy efficient bulbs, engines for hybrid and electric bulbs, as well as for parts for smart phones, LED displays, and other modern-day products. ${ }^{110}$ Similar issues will reemerge as in the China-Raw Materials case, and the USA, the EU, and Japan are in a good position to win this case if the WTO panels decide to follow a similar reasoning to the previous case. These cases raise interesting issues not only concerning essential natural resources and trade compliance, but also the role of developing countries such as China in maintaining control of important natural resources for supply chains.

It is not an accident that the adjudicatory capacity of the WTO has become a forum for dialogue in these instances, even if the 'dialogue' takes the form of a dispute. The legitimacy of the WTO in arbitrating these kinds of disputes provides winning nations with important ammunition for pressuring other countries into compliance with trade regulations; but more importantly, for finding bilateral, regional, and multilateral solutions when it comes to global supply chains and natural resources. ${ }^{111}$

\section{Recent trade and environment disputes}

The more recent trade and environment disputes are arguably different from the earlier ones in that they primarily deal with issues around subsidies, countervailing duties, and export restrictions, rather than national treatment violations. ${ }^{12}$ One of those disputes has already been discussed, involving China and its export restrictions on raw materials. ${ }^{113}$ Recent cases regarding domestic local content subsidies raise questions as to the ways in which the Agreement on Subsidies and Countervailing Measures may predominate the

109 BNA Reporter, 29 ITR 398, 15 March 2012. See China-Measures Related to the Exportation of Rare Earths, Tungsten and Molybdenum, Request for Consulationas by US, EU, and Japan, WT/DS432/433/431, 24 September 2012, available at https://www. wto.org/english/tratop_e/dispu_e/cases_e/ds431_e.htm.

110 BNA Reporter, 29 ITR 39, 15 March 2012.

111 Keisuke Iida, 'Is WTO Dispute Settlement Effective?', 10 Global Governance 207 (2004), at 210 .

112 Mark Wu and James Salzman, 'The Next Generation of Trade and Environment Conflicts: The Rise of Green Industrial Policy', draft with authors.

113 See China - Raw Materials, above n 103. See above Section III.B.3. 
trade and environment discourse in the future. ${ }^{114}$ Several WTO cases have emerged where subsidies with local content requirements are involved; for example, two cases involve subsidies and countervailing duties, triggering the GATT, and the SCM Agreement ${ }^{115}$ and two disputes deal with export restrictions on raw materials and rare earths, triggering once again provisions under the GATT. ${ }^{116}$

These cases arguably differ from early ones in that they emerge out of domestic industrial policy about how to best incentivize investment in the renewable energy sector. To the extent subsidies incentivize such investment, governments are inclined to provide them as a means of not only addressing perceived climate change threats but also as a means to increase job availability, thereby enabling governments to gather the political muster to legalize such subsidies. In this way, the trade and environment interface is evolving into more than finding ways to 'green' trade law; ${ }^{117}$ but rather, into managing domestic industrial policy that has as its goal green economic development. In this modern, 'greener' economic landscape, the WTO has potentially a larger role to play than ensuring trade compliance. In particular through its administrative capacity, it also can help redefine the manner in which economies develop and the extent to which "green" policies converge with trade goals. ${ }^{118}$

In this modern paradigm of trade, export-led strategies take the limelight. The USA and the EU have used subsidies to incentivize green growth. ${ }^{119}$ Corn subsidies in the USA, for example, became more than just an agricultural subsidy but part of the renewable energy plan for the production of corn-based ethanol. ${ }^{120}$ China and India are also using subsidies to jump-start the renewable energy sectors in their countries. Therefore, it is not surprising

${ }^{114}$ Agreement on Subsidies and Countervailing Measures Article 1.1(a)(1), 15 April 1994, Marrakesh Agreement Establishing the World Trade Organization, Annex 1A, 1867 U.N.T.S. 14 (hereinafter SCM Agreement).

115 The USA 2010 Request for WTO consultations regarding China-Wind Power Subsidies, available at http://www.ustr.gov/about-us/press-office/press-releases/2010/december/unitedstates-requests-wto-dispute-settlement-con; India-Solar Feed in Tariff; See Canada Certain Measures Affecting the Renewable Energy Generation Sector (Fapan), WT/DS412/1 (19 December 2012 Panel Report (hereinafter Canada - Renewable Energy Generation Sector (Fapan)) and Canada - Measures Relating to the Feed-in Tariff Program (EU), WT/ DS426/1 (19 December 2012 Panel Report) (hereinafter Canada - Feed-in Tariff program), consolidated and modified by WT/DS412/AB/R and WT/DS426/AB/R, (Appellate Body Report 6 May 2013). The Panel and Appellate Body in the latter two of these cases found local content rules in Ontario's Green Energy Act to be in a trade violation. See Ibid.

116 See China - Raw Materials, above n 103. See China-Rare Earths above n 109.

117 See Knox, above n 79.

${ }^{118}$ See below Section VI.

${ }^{119}$ Arunabha Ghosh and Himani Gangania, 'Governing Clean Energy Subsidies: What, Why, and How Legal?', ICTSD Global Platform on Climate Change, Trade and Sustainable Energy (August 2012).

${ }^{120}$ See Renewable Fuel Standards, US Energy Policy Act (2005) (mandating use of renewable fuel). 
that emerging WTO disputes are between industrialized countries like Japan, the USA, and the EU and increasingly include emerging economies like China and India. ${ }^{121}$ In these more modern cases, not only does the WTO adjudicatory capacity allow for more cross-fertilization of trade and environmental issues around domestic efforts to move national economies toward 'clean' economies, but it can also lead to enhanced collaboration among these nations to work together in identifying which government supported clean energy programs will be tolerated under the trade rules. ${ }^{122}$

\section{THE ADMINISTRATIVE CAPACITY OF TRADE REGIMES}

The concerns raised in the Rio Declaration did make their way to the trade regimes, not only to trade adjudication, but also with the creation of centralized bodies within the multilateral trade regime specializing in investigating the connection between trade and the environment. Furthermore, PTAs also contain administrative functions in addition to adjudicatory ones. This section will discuss the administrative capacities of the WTO and PTAs, and the ways that these have enhanced the cross-fertilization of trade and the environment.

\section{A. Secretariat and committees}

The work of the committees, such as the CTE, and the Secretariat are significant in moving forward cross-fertilization of trade and environmental issues. ${ }^{123}$ There are several discussions in the WTO regarding trade and the environment, and more specifically, trade and climate change. ${ }^{124}$ The Doha Agenda, though currently stalled, has tasked the Trade and Environment Committee with dealing with the Doha work program on trade and the environment. ${ }^{125}$ The WTO Trade and Environment Committee have held information sessions with MEA Secretariats and the

${ }^{121}$ See Canada - Renewable Energy Generation Sector (Fapan), above n 114; Canada - Feed-in Tariff Program, above n 114.

${ }^{122}$ See e.g. John Smirnow, 'U.S. -India Solar Trade Dispute at the WTO Could Spur Collaboration', Renewable Energy World.com (7 February 2013).

${ }^{123}$ See Guide to the Uruguay Round Agreements, Annex II, WTO Secretariat (1999), at 256. See Greg Schaffer, 'The World Trade Organization under Challenge: Democracy and the Law and Politics of the WTO's Treatment of Trade and Environment Matters', 25 Harvard Environmental Law Review 1 (2001).

${ }^{124}$ See e.g. 'The Thinking Ahead on International Trade (TAIT) 2nd Conference on Climate Change, Trade and Competitiveness: Issues for the WTO,' Geneva, 16-18 June 2010; 'Special Sessions' of the Trade and Environment Committee, available at http://www.wto. org/english/tratop_e/envir_e/envir_e.htm. See also Trade and Climate Change WTO-UNEP Report 2009, available at http://www.wto.org/english/res_e/booksp_e/trade_climate_change_e. pdf.

125 See DOHA WTO Ministerial 2001: Ministerial Declaration, WT/MIN(01)/Dec. 1, 20 November 2001, available at http://www.wto.org/english/thewto_e/minist_e/min01_e/mind ecl_e.htm. 
2002 World Summit on Sustainable Development in Johannesburg called for a more cooperation among United Nations Economic Program (UNEP) United Nations bodies, the Bretton Woods institutions, and the WTO. ${ }^{126}$ Furthermore, the CTE has been instrumental in providing technical assistance for developing countries regarding trade and environment concerns through regional seminars and capacity building initiatives. ${ }^{127}$

The Secretariat also plays a key role in bringing convergence between trade and environmental concerns. Regarding climate change issues, Pascal Lamy has emphasized a multilateral approach. ${ }^{128}$ In a speech with trade ministers at the Bali Climate Change Conference, Lamy stated:

'the relationship between international trade - and indeed the WTO and climate change, would be best defined by a consensual international accord on climate change that successfully embraces all major polluters. $^{129}$

But he also conceded that 'trade regulations are not, and cannot be, a substitute for environmental regulations'. He emphasized that an environmental forum such as the United Nations Framework Convention on Climate Change would be the appropriate place to address climate change concerns; however, that a climate change agreement 'must then send the WTO an appropriate signal on how its rules may best be put to the service of sustainable development'. 130

The Secretariat has followed through on this approach in its active participation in other for dealing with environmental and climate change issues. For example, to parallel the recent United Nations Climate Change Conference in Durban, it co-hosted with the International Centre for Trade and Sustainable Development (ICTSD) a Trade and Climate Change Symposium in December 2011. ${ }^{131}$ The WTO had a presence in the 2012 Rio + 20 UN Conference on Sustainable Development and published Harnessing Trade for Sustainable Development and a Green Economy in

126 See UN Report of the World Summit on Sustainable Development, Johannesburg, South Africa, August 2002, available at http://www.unmillenniumproject.org/documents/131302 wssd_report_reissued.pdf.

127 See e.g. 2010 WTO Regional Workshop on the Relationship between the Trade and Environment Regimes for Asia and the Pacific in Singapore, available at http:/www.wto. org/english/tratop_e/envir_e/envir_ta_e.htm\#national_wkshops.

128 See e.g. Pascal Lamy's Speech to a EU Parliament panel on 29 May 2008, available at http:// www.wto.org/english/news_e/sppl_e/sppl91_e.htm.

129 Pascal Lamy's speech at the Informal Trade Ministers' dialogue on Climate Change in Bali, 8-9 December 2007, available at http:/www.wto.org/english/news_e/sppl_e/sppl83_e.htm.

130 Ibid.

131 The WTO co-hosted the Symposium with the South African Department of Trade and Industry and the International Centre for Trade and Sustainable Development. See http:// www.wto.org/english/news_e/events_e/dur_trade_dec11_e.htm. 
anticipation of this. ${ }^{132}$ The annual Public Forum held at the WTO headquarters provides another means of encouraging dialogue among trade and non-trade interest groups, and has focused several discussions on mitigation of climate change. ${ }^{133}$

\section{B. The impact of committee decisions on the adjudicatory function}

The negotiated efforts taking place at the committee level of the WTO can not be ignored. Specifically, the WTO trade and environment committee attempts to move the dialogue forward as it pertains to specific environmental issues that trade impacts, such as fisheries and agriculture but also governance issues such as the relationship between the WTO and Multilateral Environmental Agreements. ${ }^{134}$ Furthermore, the 2001 Doha agenda addresses specific issues covered in the committees, such as the prevention of 'green protectionism' and labeling requirements for environmental purposes. ${ }^{135}$ However, with the recent impasse of the Doha Round, Doha Ministerial decisions and WTO Committee decisions seem to be gaining in importance at the adjudicatory level.

Subject to certain procedural requirements, the WTO Ministerial Conference and General Council has 'the exclusive authority to adopt interpretations' of WTO agreements under Article IX:2 of the Marrakesh Agreement Establishing the World Trade Organization. Recently, WTO dispute settlement bodies have referred to WTO Committee and Ministerial decisions as 'subsequent agreement[s]' within the meaning of Article 31(3)(a) of the Vienna Convention. ${ }^{136}$ Article 31(3)(1) of the Vienna Convention states that a treaty should be interpreted in accordance with 'any subsequent agreement between the parties regarding the interpretation of the treaty or the application of its provisions'. ${ }^{137}$

In U.S. - Clove Cigarettes, for example, Indonesia alleged that the USA regulation prohibiting cigarettes containing flavors other than tobacco or menthol violated trade provisions of the TBT Agreement and the GATT;

132 See "Harnessing Trade for Sustainable Development and a Green Economy," available at http://www.wto.org/english/res_e/publications_e/brochure_rio_20_e.pdf.

133 See e.g. WTO Public Forum 2007 session on 'The Role of Trade in Supporting International Efforts to Mitigate Climate Change', available at http://www.wto.org/english/ forums_e/public_forum2007_e/public_forum07_e.htm.

${ }^{134}$ See e.g. 'List of Documents', WT/CTE/INF/5/Rev.10, available at http://www.wto.org/eng lish/tratop_e/envir_e/wrk_committee_e.htm (listing the documents circulated and discussed at the CTE until November 2011).

135 See DOHA WTO Ministerial 2001: Ministerial Declaration, WT/MIN(01)/Dec. 1, November 20, 2001, para 31 available at http://www.wto.org/english/thewto_e/minist_e/ min01_e/mindecl_e.htm; see Doha Agenda for the CTE, available at http://www.wto.org/ english/tratop_e/envir_e/cte_doha_e.htm.

136 See Vienna Convention on the Law of Treaties, Article (3)(a), 23 May 1969, 1155 U.N.T.S. 331.

137 Ibid. 
and more specifically, that the USA did not publish the requirements within a 'reasonable interval' under Article 2.12 of the TBT Agreement. The Appellate Body looked to a Doha Ministerial Decision that stated that 'reasonable interval' should be understood to mean a timeframe of not less than six months, 'except when this would be ineffective in fulfilling the legitimate objectives pursued by a technical regulation.' 138

In US-Tuna II, the Appellate Body, in order to decide whether the USA in enacting its dolphin-safe labeling scheme was in violation of Article 2.4 of the TBT Agreement, had to determine whether the AIDCP scheme complied with the definition of 'international standards' under the TBT Agreement. Article 2.4 states that Members shall use relevant internationals as 'a basis for their technical regulations except when such international standards... would be an ineffective or inappropriate means for the fulfillment of the legitimate objectives pursued...139 However, 'international standards' are not defined in the TBT Agreement and the panel instead looked to the definition in the ISO/IEC Guide. ${ }^{140}$ While the Appellate Body did not disagree with the panel's judicial discretion here, it concluded that the TBT Annex 1 would take precedence to the extent of inconsistency. Since Annex 1 states that a standard is approved by a 'body' rather than an 'organization (as in the ISO/IEC Guide),' the determination of whether the AIDCP scheme was adopted by and 'international standardizing body' had to be made according to this definition. ${ }^{141}$ Furthermore, such a body must be 'open' and 'recognized' in its standardization activities. The Appellate Body looked to the TBT Committee Decision to interpret 'open' and 'recognized activities in standardization' by declaring that this Decision was in fact a 'subsequent agreement' within the meaning of Article 31(3)(a) of the Vienna Convention on the Law of Treaties. ${ }^{142}$ Contrary to the Panel decision, the Appellate Body found that the AIDCP scheme was not 'open' because membership was conditioned to an invitation; and therefore, not a relevant international standard under Article 2.4. ${ }^{143}$

Though the Appellate Decision regarding the USA violation of Article 2.4 did not change the Panel's outcome that the US regulatory scheme was not in violation of Article 2.4, the reasoning was very different and significant. In taking the position that (i) the TBT Annex 1 would take precedence over the ISO/IEC Guide where there was inconsistency, and (ii) that the TBT

\footnotetext{
${ }^{138}$ See US - Clove Cigarettes AB Report, above n 1, paras 266; 267-268.

139 See Ibid, para 343. See also TBT Agreement, above n 42 Article 2.4.

${ }^{140}$ See US - Tuna II Panel Report, above n 23 para 7.663; see ISO/IEC (International Organization for Standardization/International Electrotechnical Commission) Guide 2:1991, General Terms and their Definitions concerning Standardization and Related Activities (6th edn, 1991) (hereinafter ISO/IEC Guide).

${ }^{141}$ US - Tuna II AB Report, above n 23 paras 353-54.

${ }^{142}$ See Ibid, at para 372.

${ }^{143}$ See Ibid, at paras 398-99.
} 
Committee Decision not only provided interpretative guidance but also had legal force as to legal interpretations of the TBT Agreement, the Appellate Body took an important step as to the applicability of Committee decisions in judicial decisions. Using a dialogical lens, the Appellate Body's willingness in both these cases to incorporate Ministerial and Committee decisions as rule of law shows that it can use its judicial discretion to 'communicate' with the administrative capacity of the WTO.

\section{Preferential trade agreements}

Post 1994, there was a surge in regional and bilateral trade agreements. Unique to these agreements, as compared to the WTO Covered Agreements, was that the relationship of environmental issues with trade was explicitly incorporated within the legal framework of trade in specific ways. Some PTAs, like the NAFTA, even formally recognized international environmental agreements into their trade structure. The first significant trade agreements of this kind were the Maastricht Treaty (EU), ${ }^{144}$ the NAFTA, ${ }^{145}$ and MERCOSUR. ${ }^{146}$ While aspiring to very different goals, both address environmental issues as well as other regulatory concerns such as labor. Within the legal framework of these PTAs, there are administrative and adjudicatory functions that contribute to the cross-fertilization of trade and environmental issues.

\section{Some US regional trade agreements}

The rising concerns regarding the impact trade may have on the environment culminated in the passing of NAFTA, the first PTA to explicitly incorporate environmental concerns into a trade agreement. ${ }^{147}$ There are examples of the interplay of environment and trade throughout the NAFTA. The Chapters on Standard Related Measures and Agriculture and Phytosanitary Measures both specifically attempt to balance the need of states to protect the environment and to expand free trade. Furthermore, the chapter on foreign direct investment recognizes that the investment chapter should not be construed

${ }^{144}$ Treaty on European Union [TEU, Maastricht Treaty], 7 February 1992, 1992 O.J. (C191) 1; 31 I.L.M. 253 (1992). This article will not focus on the EU, however, it is important to note that the EU has explicitly tried to deal with issues around the environment and sustainability through, for example, Emissions Trading System (ETS). See EU Emissions Trading System (2008).

${ }^{145}$ North American Free Trade Agreement Between the Government of the United States of America, the Government of Canada and the Government of the United Mexican States, 17 December 1992, 32 I.L.M. 605, reprinted in The NAFTA (United States Government Printing Office ed., 1993) (hereinafter NAFTA).

${ }^{146}$ See Treaty of Asunción, 26 March 1991, reprinted in 30 International Legal Materials 1044 (1991). Members include Argentina, Brazil, Uruguay, and Paraguay and associated members are Chile and Bolivia (hereinafter MERCOSUR).

${ }^{147}$ See North American Agreement on Environmental Cooperation, 14 September 1993, 32 I.L.M. 1480, reprinted in The NAFTA Supplemental Agreements (United States Government Printing Office ed., 1993) (hereinafter NAAEC). 
as preventing Parties from adopting and enforcing domestic environmental measures. ${ }^{148}$ The NAFTA contains several references to MEA's and urges NAFTA parties who are members of those treaties to not use the NAFTA as a means for noncompliance with those treaties. ${ }^{149}$ Article 104, for example, is the result of the bargaining of Canadian, USA, and Mexican stakeholders regarding environmental issues and trade. Of particular interest to Canada at the time, it recognizes certain international environmental agreements as having priority over the NAFTA in the event there is inconsistency in the compliance with the Agreements. The Montreal Protocol on Substances that Deplete the Ozone Layer, the Basel Convention on the Control of Transboundary Movements of Hazardous Wastes and Their Disposal, and the Convention on International Trade in Endangered Species of Wild Fauna and Flora are among these. ${ }^{150}$ While the NAFTA incorporates certain MEAs into its provisions, the WTO has not yet taken a position on its relationship to MEAs and has not incorporated them into its Covered Agreements. ${ }^{151}$

In addition to specific provisions dealing with environmental regulations and some MEAs, the NAFTA provides a side agreement on environmental issues to the trade agreement. The North American Agreement on Environmental Cooperation (NAAEC) was an attempt not only to bring environmental issues into the trade discourse, but also a way of converging the softer qualities of international environmental frameworks into the harder framework of a free trade agreement. However, the NAAEC arguably does little to raise environmental standards, for it only requires NAFTA Parties to enforce their already existing environmental laws. ${ }^{152}$ Though it contains institutional structure through the Commission for Environmental Cooperation (CEC) and its dispute settlement body, ${ }^{153}$ the NAAEC suffers from its inherent internal structure. The Council consists of cabinet-level representatives of each of the Parties. ${ }^{154}$ Furthermore, the Council selects

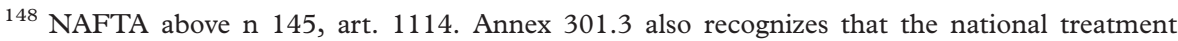
provision of NAFTA shall not apply to certain environmental measures within certain international agreements to which the Parties are already signatories.

149 NAFTA above n 145, arts. 103 \& 104.

150 See NAFTA above n 145, Art. 104. Basel Convention on the Control of Transboundary Movements of Hazardous Wastes and Their Disposal, 28 I.L.M. 657 (1989), 22 March 1989, 1673 U.N.T.S. 125; Montreal Protocol on Substances That Deplete the Ozone Layer, 16 September 1987, 26 I.L.M. 1550 (1 January 1989); Convention on International Trade in Endangered Species of Wild Fauna and Flora, 3 March 1973, 27 U.S.T. 1087, 993 U.N.T.S. 243; 12 I.L.M. 1085 (1973).

151 But see, 'The Doha Mandate on Multilateral Environmental Agreements,' available at http:// www.wto.org/english/tratop_e/envir_e/envir_neg_mea_e.htm.

152 See NAAEC, above n 147, Articles 14-15.

153 Ibid, at Part 3. The Commission consists of a Council, Secretariat, and Joint Public Advisory Committee.

154 See NAAEC, above n 147, Article 9. 
the Executive Director of the Secretariat. ${ }^{155}$ These factors subject the agreement to domestic politics of each NAFTA Party; and therefore, its execution can become very politicized. ${ }^{156}$ Despite these defects, the CEC provides a central administrative forum for discussion of environmental matters among the North American partners and for further coordination and harmonization of environmental regulations among the three nations. Articles 14 and 15 provide for citizen submissions, both by non-governmental organizations and individuals, to the Secretariat asserting a Party's failure to comply with its own environmental laws. This process has resulted in several public submission reports, which has also contributed to broader awareness of the connection between trade and environmental issues among trade and nontrade communities. ${ }^{157}$ Furthermore, the NAAEC provides for a Joint Public Advisory Committee, consisting of 15 members of civil society and which advises the Council on environmental matters within the scope of the environmental side agreement. ${ }^{158}$ The CEC, though weak in its ability to raise or enforce existing environmental standards, has played an important role for more discourse on environmental and trade matters, not only through its citizen submission process which allows for enhanced participation from non-trade stakeholders, but also through research forums and workshops, publication of annual reports, and public commentary to CEC research. ${ }^{159}$ It has even included on its agenda the need to promote harmonization for renewable electricity markets in North America. The CEC published in 2007 an Executive Summary on the topic, providing an overview of key market demand and supply side drivers for renewable electricity in the three NAFTA countries and calling for enhanced ways of furthering cooperation and harmonization in this area for the NAFTA region. ${ }^{160}$ In these ways, the NAAEC, through the administrative function of the CEC, has provided a more formalized forum for discourse of trade, environmental, and even energy issues, leading to enhanced cross-fertilization.

The NAAEC, living alongside NAFTA, also contains an adjudicatory mechanism so that parties can bring a claim of an environmental dispute. While this mechanism is not as strong as in the investment context, where monetary damages are granted if a violation is found, it does provide injured

155 See NAAEC, above n 147, Aricles 11 and 15.

${ }^{156}$ See Steve Charnovitz, The NAFTA Environmental Side Agreement: Implications for Environmental Cooperation, Trade Policy, and American Treatymaking, 8 Temple International and Comparative Law Journal 257, 263-264, 281-282.

157 See NAAEC, above n 147, Article 14.

${ }^{158}$ See NAAEC above n 147, Article 16.

${ }^{159}$ See generally, CEC Annual Reports from 1995-2006, available at http://www.cec.org/Page. asp?PageID $=30107 \&$ SiteNodeID $=648$. See also 'Public Commentary to CEC research and reports', available at http://www.cec.org/Page.asp?PageID=1226\&ContentID=\&SiteNodeID= 222\&BL_ExpandID=.

${ }^{160}$ See CEC Executive Summary, 'Fostering Renewable Electricity Markets in North America', available at http://www.cec.org/Storage/59/5125_FREM_en.pdf. 
parties with an adjudicatory forum for the enforcement of domestic environmental regulations. ${ }^{161}$ However, this mechanism has never been used. Administrative capacity of the NAAEC has been more influential in crossfertilizing trade and environmental issues at the regional level than its adjudicatory function. The same phenomenon will be true for the MERCOSUR. ${ }^{162}$

\section{MERCOSUR}

The MERCOSUR is a framework that provides guidelines for a common market in the Cono Sur of Latin America, which allows for free movement in goods, services, and capital, much like the Treaty of Rome provided for the European Union. ${ }^{163}$ With an institutional structure more robust than the NAFTA, the administrative capacity is in the Council and the Common Market Group, with the Council having the 'political leadership' to act diplomatically on behalf of the MERCOSUR countries on trade issues. ${ }^{164}$ The Common Market Group implements the Council's decision, monitors compliance, and proposes measures and work programs to enhance trade liberalization. ${ }^{165}$ It has an 'executive' function, consisting of members of the Ministries of Foreign Affairs, of Economy, and Central Banks of the Members. ${ }^{166}$ It also has as part of its structure the Commerce Commission of MERCOSUR, the Joint Parliamentary Commission, and the Consulting Economic Social Forum. ${ }^{167}$ Working groups work on specific areas such as fiscal and monetary policy, agriculture, and energy policy to coordinate policies. Decisions by the Council or the Common Market Group must be approved by the individual members. ${ }^{168}$ Despite little institutional activity, MERCOSUR was an important catalyst in promoting trade among its members, increasing trade among them by $250 \%$ from 1991 to $1995 .^{169}$

With respect to the environment, the MERCOSUR does contain a framework for dealing with issues concerning the environment, sustainability, and

161 See NAAEC, above n 147, Articles 34, 36, and Annex 34.

162 See below Section IV.C.2.

163 See Raj Bhala and Kevin Kennedy, World Trade Law § 2-5(b)(1)(A). The MERCOSUR does not include free movement of labor and people as in the EU. Members of MERCOSUR include Brazil, Argentina, Paraguay, and Uruguay, with Chile and Bolivia associated members. Venezuela became the newest member of MERCOSUR in 2006. See Protocolo de Adesão da República Bolivariana da Venezuela ao Mercosul, available at http://www.mercosur.int/msweb/portal\%20intermediario/pt/index.htm.

164 Treaty of Asunción, Chapter II, Articles 9-10.

165 See Ibid Article 13.

166 See Ibid Article 14.

167 Raquel Aguero, 'Environmental Legislation in MERCOSUR' at 114, in 1st International Environmental Compliance and Enforcement in Latin America.

168 See Bhala and Kennedy, above n 163 at $\S 2-5(b)(1)(G)$.

169 Trade increased from $\$ 4$ billion in 1990 to more than $\$ 14$ billion in 1995 . See id at $\S$ $2-5(\mathrm{~b})(1)(\mathrm{B})$. 
energy. The Treaty of Asunción lays out as one of its objectives the efficient use of its natural resources and the preservation of the environment. ${ }^{170}$ The Canela Declaration committed the heads of states of the MERCOSUR members to share the responsibility in dealing with environmental issues. ${ }^{171}$ The Protocol of Ouro Preto allows for public participation from public and private sectors, including those connected to the environment. Primarily through the work of the Subgroup No. 6 of Environment, and resolutions/directives passed by the Common Market Group, several legal instruments within the MERCOSUR provide for internal dialogical interfaces between trade and the environment. For example, the Council and Common Market Group passed resolutions involving pesticides, energy policies, and hazardous products that eventually led to the formation of an informal working group to study environmental laws and standards in the four member countries, resulting in 1994 in the establishment of guidelines for increasing harmonization of standards, reduction in pollution, fair conditions for commerce, adoption of renewable natural resources, among other things. ${ }^{172}$ Directives have attempted to address some of these areas directly, and establish the importance of environmental sustainability and development for the MERCOSUR. In particular, the Resolution 10/94 was clear to connect the need for the 'least degree of environmental deterioration in productive processes and in exchange products.... ${ }^{173}$ Furthermore, some directives make compulsory license qualifications and evaluation of environmental impacts for investments. ${ }^{174}$ The Commission on Environmental Cooperation, established in $1992,{ }^{175}$ works on issues of harmonization of environmental standards and restrictions to the exploitation of resources, though no harmonization procedures have been adopted per se. However, a 'Procedure for the Analysis and Resolution of the Non-Tariff Measures and Restrictions' is part of the MERCOSUR documents. ${ }^{176}$ Though there is a GATT Article XX equivalent in the MERCOSUR, there is no similar

${ }^{170}$ See Treaty of Asunción, Preamble. For an overview of environmental policies in the MERCOSUR, see generally Fabio Morosini, 'The MERCOSUR and WTO Retreaded Tires Dispute: Rehabilitating Regulatory Competition in International Trade and Environmental Regulation', 59-65 (2008), available at http://www.ssrn.com/link/SIELInaugural-Conference.html.

${ }^{171}$ See Declaração de Canela dos Presidentes dos Países do Cone Sul Prévia à Conferência das Nações Unidos sobre Meio Ambiente e Desenvolvimento, available at http://www.mercosur. $\mathrm{int} / \mathrm{msweb} /$ portal\%20intermediario/pt/index.htm.

172 See Resolution 10/94 of the Common Market Group. A summary of these guidelines is in Aguero, above $\mathrm{n} 167$ at 115 .

${ }^{173}$ See REMA/Rec 10/94, available in Spanish at http://www.mercosur.int/innovaportal/v/3097/ 1/secretaria/resoluciones_1994. See also, Aguero, above n 167 at 115.

${ }^{174}$ See Aguero, above n 167. See also, GMC Resolution 57/93, available at http://www.mercosur.int/msweb/portal\%20intermediario/pt/index.htm (visited 30 October 2007).

${ }^{175}$ Decreto Presidencial No. 2.241, de 2 de junho de 1997, D.O.U. de 03.06.1997 (Brazil), Article 4.

${ }^{176}$ See Ibid at 116 . 
chapeau, facilitating adjudicatory discretion as to the legitimacy of national environmental measures. ${ }^{177}$ However, Article 50 of the Montevideo Treaty recognizes that trade measures should not impede domestic regulatory measures pursuing legitimate objectives, including 'the protection of the life and health of persons, animals, and plants'. ${ }^{178}$

The dialogical aspects of the MERCOSUR, as they pertain to trade and environment, are found primarily within its administrative capacity, where the Common Market Group has implemented resolutions dealing with the environment, and even more so with respect to Phytosanitary measures regarding trade in animal and agricultural products. ${ }^{179}$ One 1994 resolution even addressed limits by Members on toxic gas emissions from vehicles with the hope that they would work to harmonize standards in this regard and require compliance to established emissions standards. ${ }^{180}$ Furthermore, the working groups, especially Subgroup No. 6 on the environment, discuss and implement guidelines for dealing with social issues that intersect with trade such as sustainable development and preservation of natural resources.

However, less activity has originated from the adjudicatory capacity of the MERCOSUR, an evolving organ that was more consolidated after the Protocol of Olivos in 2002. ${ }^{181}$ This Protocol not only reinforced the dispute settlement mechanism put in place by the Treaty of Asunción, but also a Permanent Appellate Tribunal, el Tribunal Permanente de Revisión. ${ }^{182}$ It also allows Members to choose the WTO dispute settlement body where it has jurisdiction, much like the NAFTA under Article 2005. ${ }^{183}$ Though there has been little MERCOSUR adjudicatory activity on trade and environment, one does stand out as particularly important for the dialogical interface between trade and the environment. ${ }^{184}$ Brazil - Measures Affecting Imports of Retreaded Tyres will be discussed in more detail in Section IV of this article because it not only highlights the emerging dialogical aspects resulting from the adjudicatory

177 See Morosini, above n 170, at 61.

178 See Ibid. See also, See Annex I to the Asunción Treaty - Programa de Liberalização Comercial, Article 2(b), available at http:/www.interlegis.gov.br/processo_legislativo/copy_ of_20020319150524/20030529151030/TRTASS02.HTM\#E49E2.

179 See e.g. MERCOSUR/GMC/Res No. 71/1994-62/1994, available in Spanish at http://www. mercosur.int/innovaportal/v/3097/1/secretaria/resoluciones_1994.

180 See MERCOSUL/GMC/Res. No. 84/94, available in Portuguese at http://www.mercosur.int/ innovaportal/v/3097/1/secretaria/resoluciones_1994. See also, GMC Resolution 9/91, available at http://www.mercosur.int/msweb/portal\%20intermediario/pt/index.htm (visited 30 October 2007).

181 The Olivos Protocol for the Settlement of Disputes in MERCOSUR, 18 February 2002, available at 42 ILM 2 (2003).

182 See Ibid, Article 1.

183 See Ibid Article (1)(2).

184 Prior to Brazil - Measures Affecting Imports of Retreaded Tyres, there was one case before the MERCOSUR Permanent Appellate Tribunal that dealt with a Brazilian phytosanitary measure on imports from Argentina. For more on this case, see generally Morosini, above n 169 at $66-69$. 
capacity internal to the MERCOSUR and its ability to cross-fertilize trade and environment issues within its own MERCOSUR trade jurisprudence, but it also demonstrates the impact that overlapping multilateral and regional regimes may have in the convergence of trade and environmental issues. ${ }^{185}$

While PTAs that incorporate adjudicatory and administrative capacities in order to manage trade and environment concerns create opportunity for regional and bilateral cooperation and coordination in this area, they also enhance fragmentation and uncertainty as to the ability of regional partners to create environmental policy regionally rather than multilaterally. Furthermore, PTA's represent new fora through which states may bring disputes concerning issues of trade and environment. ${ }^{186}$ There is little guidance as to the relationship between the multilateral and regional regimes in this context. While such fragmentation may create opportunities for more dialogue and negotiation, it also increases ambiguity, pushing trade and environmental issues onto the international sphere of inter-systemic interactions and processes and away from local governance and citizen participation. This dynamic, however, further contributes the cross-fertilization of trade and environmental issues, resulting in dialogical effects.

\section{DIALOGICAL EFFECTS OF FRAGMENTATION}

There can be more than one trade regime under which a regulation may be adjudicated. As already discussed, several PTAs may address issues of the environment when dealing with trade. While the WTO agreements seem to recognize that environmental regulations may come under its Covered Agreements like the GATT, the TBT, and SPS Agreements, there is no multilateral trade framework that formally deals with environmental issues. On the other hand, as discussed, many PTAs do address issues of trade and the environment in formal ways, though to varying degrees. However, many also allow parties to choose whether to adjudicate disputes under the regional agreement or the WTO, as seen in NAFTA and MERCOSUR for example. As a result, jurisdictional overlaps arise as disputing parties strategically choose whether to bring a trade dispute under a regional tribunal or the WTO DSB. Having the option to adjudicate regional environmental disputes at the multilateral level is in part a strategic choice for relevant parties, because of the political weight of the WTO. Furthermore, other interested WTO members may submit briefs. ${ }^{187}$ Trade and non-trade interests may converge when

185 See below Section V.A.

${ }^{186}$ Joost Pauwelyn and Luiz Eduardo Ribeiro Salles, 'Forum Shopping Before International Tribunals: (Real) Concerns, (Im)Possible Solutions', 42 Cornell International Law Journal 77 (2009).

${ }^{187}$ Hansel T. Pham, 'Developing Countries and the WTO: The Need for More Mediation in the DSU', 9 Harvard Negotiation Law Review 331 (2004), at 345. 
different international adjudicatory regimes have jurisdiction for related issues, such as in the well-known Chile-Swordfish case submitted both to the WTO and the Law of the Sea Convention (UNCLOS). ${ }^{188}$

At times, this kind of interface may illuminate overlapping interests between seemingly different sets of policy; such as, the environmental and trade interests. Other times, it may demonstrate the overlapping interests of private and public actors and the ways in which they interact within the various regimes in the international sphere. ${ }^{189}$ As a procedural matter, though, these types of cases take the form of overlapping fora through which complainants may bring a trade (or investment) dispute.

Adjudicatory overlaps may exist between private rights of action under the investor-state arbitration context and public rights of action under the trade. ${ }^{190}$ For example, Corn Products International v United Mexican States, involving a US investor with the largest market share in high fructose corn syrup (HFCS) in Mexico, was a Chapter 11 investor-state dispute against the Mexican government for passing a tax on soda bottlers using HFCS. ${ }^{191}$ There was no comparable tax for users of sugar. In 2004, the US government brought Mexico - Tax Measures on Soft Drinks and other Beverages before the WTO, alleging that this tax was protectionist and in violation of national treatment provisions under the GATT. ${ }^{192}$ Mexico argued that the case needed to be resolved under the NAFTA since Mexico had already tried to convene a Chapter 20 NAFTA panel regarding the issue. However, the WTO panel reasoned that it had jurisdiction over such matters and ignored the reference to NAFTA, and then proceeded to find Mexico's tax in violation of its trade obligations under the GATT. The NAFTA investor-state

${ }^{188}$ Chile - Measures Affecting the Transit and Importation of Swordfish, Request for Consultations by the European Communities, WTO/WT/DS193/1, April 26, 2000 (hereinafter, Chile Swordfish). See International Tribunal for the Law of the Sea, Case concerning the Conservation and Sustainable Exploitation of Swordfish Stocks in the South-Eastern Pacific Ocean, Constitution of Chamber, Order 2000/3, 20 December 2000, para 2.

189 Elizabeth Trujillo, 'From Here to Beijing: Public/Private Overlaps in Trade and Their Effects on U.S. Law', Loyola University Chicago Law Journal 691 (2009).

190 See Ibid.

191 Request for Institution of Arbitration Proceedings, Corn Products International $v$ United Mexican States 21 October 2003 (hereinafter Corn Products International).

192 Request for the Establishment on a Panel by the United States, Mexico - Tax Measures on Soft Drinks and other Beverages, WT/DS308/R, adopted on 24 March 2006 (hereinafter Mexico-Tax Measures). Earlier antidumping disputes involving corn products had concluded in NAFTA Chapter 19 trade panel and WTO Appellate Body finding Mexico in violation of its trade obligations under their respective agreements. See Mexico-Anti-dumping Investigation of High Fructose Corn Syrup from the United States, WT/DS132/R (28 January 2000) (adopted 25 February 2000); NAFTA Chapter 19 Tribunal in Review of the Final Determination of the Antidumping Investigation on Imports of High Fructose Corn Syrup, Originating from the United States of America, Mex. U.S. 98-1904-01 (3 August 2001) (hereinafter Imports of High Fructose Corn Syrup). 
tribunal finally decided against Mexico and awarded the US investor, Corn Products International, $\$ 58.4$ million from the government of Mexico. ${ }^{193}$ This was finally paid in January 2011. ${ }^{194}$

The sugar disputes between the USA and Mexico illustrate that public rights of action under trade may collide with private rights of action under investment regimes. ${ }^{195}$ These jurisdictional overlaps, where private investors bring an investment dispute against a state at the regional level and almost simultaneously the state of the investor will bring a trade dispute with similar questions as the investment dispute for adjudication under a WTO panel, create opportunities for heightened conflict and as a result, for subsequent dialogue and negotiation. ${ }^{196}$ In 2006, the USA and Mexico reached a NAFTA sugar agreement where the USA promised to increase market share of Mexican sugar into the USA and Mexico would eliminate tariffs on US HFCS. ${ }^{197}$ The agreement also called for the removal of all barriers in sugar and sweetener trade between the two countries by 1 January $2008 .{ }^{198}$ Though this sugar dispute does not directly implicate environmental issues, it highlights the dialogical impact that fragmentation of investment and trade regimes may have when various public and private interests collide within a fragmented inter-systemic international landscape.

The public/private adjudicatory overlaps have important implications for regulation, particularly if similar parties are involved in the trade and the investment dispute, both being brought around the same time, and where substantive legal issues may overlap, as in the case in the NAFTA and WTO cases involving HFCS. ${ }^{199}$ Despite jurisdictional fragmentation as a result of multiple fora, jurisdictional clashes may also enhance opportunities for dialogue and regulatory bargaining among states regarding the domestic regulatory measures that will be tolerated vis-à-vis their trade obligations. ${ }^{200}$

193 Corn Products International v United Mexican States, 15 January 2008, ICSID Case No. $\mathrm{ARB}(\mathrm{AF}) / 04 / 01$.

${ }^{194}$ See 'News Highlights' for Corn Products International, 26 January 2011, available at http:// www.cornproducts.com/newsroom/news_highlights/corn_products_receives_584_million_ related_to_nafta_tribunal_judgment/.

195 See generally, Trujillo, From Here to Beijing supra note 189 (discussing vertical and horizontal overlaps among public and private rights of action).

196 See Ibid.

${ }^{197}$ See Ana Leroy and James J. Shea, 'United State and Mexico Strike NAFTA Sugar Agreement', North American Free Trade and Investment Report, 15 August 2006.

198 See Magda Kornis, 'U.S. Corn Sweeteners and Mexican Sugar: Agreement at Last', U.S. ITC Journal of International Commerce and Economics, December 2006.

${ }^{199}$ See Mexico - Tax Measures, above n 192; See also Corn Products International, above n 193. For general discussion regarding the jurisdictional and substantive overlaps among trade and investment regimes, see Trujillo, From Here to Beijing supra note 189.

${ }^{200}$ Kal Raustiala and David. G. Victor, 'The Regime Complex for Plant Genetic Resources', 58 International Organizations (2004), at 277310. Paul Schiff Berman, 'Global Legal Pluralism', 80 Southern California Law Review 1155 (2007). 


\section{A. Brazil - Retreaded Tyres}

It is unclear how trade tribunals deal with issues where both a regional tribunal and the multilateral one have jurisdiction. For the most part, the way that the WTO panels have addressed this issue is to hear cases where the WTO has jurisdiction, ignoring the question of whether the dispute should be heard at the regional level as was done in Mexico - Tax Measures. ${ }^{201}$ However, Brazil - Measures Affecting Imports of Retreaded Tyres explicitly dealt with a decision from a regional tribunal concerning a local regulation for recycled products, ruling that the regional tribunal decision was in violation of the WTO rules. ${ }^{202}$ This case illustrates that, despite the fragmentation, the overlapping trade regimes may in fact converge on trade and environment issues and result in a top-down adjudication concerning a decision by a regional trade tribunal.

Brazil - Retreaded Tyres was the first WTO case dealing with recycled waste products. The EU initially brought this case claiming that Brazil's ban and penalties on retreaded tire imports from non-MERCOSUR countries amounted to a trade restriction prohibited under GATT Articles XI and Article III. Brazil had passed the measure in accordance with a MERCOSUR exemption for the ban. The MERCOSUR panel decision had recognized the commitment by Members to the environment and found that such a ban could be justified as pursuing a legitimate environmental objective. ${ }^{203}$ In particular, it accepted that the precautionary principle could justify such measures in certain cases. However, the MERCOSUR Appellate Body Tribunal ultimately disagreed with the Panel decision and found the measure to be trade restrictive, opining that the alleged environmental harm was not serious enough and that the measure did not meet the environmental objectives. ${ }^{204}$ Interestingly, the Appellate Body Tribunal showed the same reserve as WTO bodies in supporting the precautionary principle, ruling on the side of free trade and articulating that it was the foundation principle of free trade that primarily governed the MERCOSUR. ${ }^{205}$

In the WTO case, Brazil claimed that the ban was justified under Article $\mathrm{XX}(\mathrm{b})$ of the GATT because it was 'necessary' in order to protect human, animal and/or plant life or health. It used a balancing test to weigh 1) Brazil's objectives to prevent life-threatening diseases brought on by the accumulation of waste tires in the waste sites, 2) the relative nexus of this policy to achieve those objectives, and 3) the degree to which the measure restricted

\footnotetext{
${ }^{201}$ See e.g. Mexico - Tax Measures above n 192. See also Trujllo, above n 80.

202 Brazil - Measures Affecting Imports of Retreaded Tyres, WT/DS332/R (2007) (hereinafter Brazil - Retreaded Tyres AB Report)

203 See Morosini, above n 170, at 91. See also Montevideo Treaty, Article 50(d) (1980).

${ }^{204}$ See Argentina Appellate Body Report, para 17.

205 See Morosini, above n 170, at 87-88.
} 
trade. ${ }^{206}$ Although the WTO panel found that the measure was in violation of GATT Article XI:1 and Article III, it analyzed the viability of the measure under Article XX more narrowly. The Panel found that this import ban was a legitimate regulation that pursued the protection of human, animal or plant life and was necessary to fulfill Brazil's objectives. ${ }^{207}$ Though the Panel ultimately found the measure trade restrictive, the Panel also found the environmental measure necessary to further Brazil's objective. However, it decided that the measure was applied in a discriminatory fashion. ${ }^{208}$ In line with previous jurisprudence, the Appellate Body rejected the Panel's narrow application of Article XX's chapeau and found the ban to be arbitrary and unjustifiable, and not the least restrictive means of pursuing the environmental objective. ${ }^{209}$ Furthermore, it did not find the measure justified under Article XX(b).

This case not only had implications for WTO treatment of regional environmental regulations, it also showed the willingness of recent WTO panels to consider environmental regulations at the regional level and the viability of decisions by regional tribunals under the GATT. Though ultimately not upholding the measure, it was significant that a WTO panel actually recognized that the measure was not arbitrary or discriminatory per se and that it was legitimate in furthering Brazil's environmental objective. ${ }^{210}$ Arguably, the MERCOSUR Appellate Body Tribunal was even less sympathetic to the environmental concerns than the WTO panel, which went to great lengths to justify the environmental objectives of Brazil's ban. ${ }^{211}$ Overall, though, it was a bold WTO decision. First, it was the first WTO case dealing with recycled waste products. Second, it considered whether a regional tribunal's assessment of an environmental measure; namely the exception under MERCOSUR, could be justified under Article XX. Third, it illustrated the use of judicial discretion by WTO dispute settlement bodies which, though the Appellate Body ultimately found the exception invalid under the Article XX chapeau, the Panel did indeed find it to be a necessary regulation to further Brazil's environmental objective.

Brazil-Retreaded Tyres contains several dialogical elements. It shows the cross-fertilization of trade and environmental issues within the MERCOSUR. First the work of the MERCOSUR adjudicatory processes balances trade goals with those of protecting the environment, thereby crossfertilizing the two domains. The willingness of the MERCOSUR panel to consider the precautionary principle in justifying an environmental regulation

\footnotetext{
206 See Panel Report, Brazil - Measures Affecting Imports of Retreaded Tyres, WT/DS332/R (12 June 2007) (hereinafter Brazil - Retreaded Tyres Panel Report).

207 See Ibid, para 3.

208 See Ibid, para 7.355.

209 Brazil - Retreaded Tyres AB Report, above n 202, paras 224-34.

210 See Ibid, at para 3, 7.215. The Appellate Body disagreed with this analysis.

211 See Morosini, above n 170 at 112.
} 
under the trade agreement demonstrates such cross-fertilization. Second, the administrative capacity of the MERCOSUR, in passing resolutions and guidelines regarding environmental measures, has demonstrated a formal cross-fertilization and expansion of this regional trade regime into the environmental. Finally, the fragmentary nature of trade regimes allowed for the MERCOSUR case to confront the multilateral sphere through a WTO adjudication in Brazil-Recycled Tyres. This case illustrated the multiple centers for decision-making that exist for issues concerning trade and the environment. Furthermore, these multiple centers converged within the adjudicatory capacity of the WTO in a top-down ruling that has impact on the relationship of WTO and regional trade regimes and on the trade and environmental interface.

\section{B. Overlapping public and private regimes}

Within the NAFTA, and other subsequent PTAs, there are protections for investors of the members of those agreements. Effectively, the ability of investors of trading partners to bring an investor-state dispute brings private rights within the parameters of a trade agreement, a public regime involving the trading rights of states. This phenomenon has allowed for overlaps of public rights of action and private rights of action on similar substantive issues. ${ }^{212}$ It also creates opportunities for cross-fertilization of trade and environment issues. To better understand the cross-fertilization of trade and environment, investor-state regimes (especially those found in trade agreements) should be seen as part of this dynamic, rather than as a regime that functions in isolation of legal measures to increase trade compliance.

Corn Products International $v$ United Mexican States, as discussed above, illustrated the overlapping public and private regime phenomena where heightened conflict through multiple fora may result in cross-fertilization of trade and domestic regulatory issues and culminate in negotiation. ${ }^{213}$ Other NAFTA investor-state disputes, however, have dealt with environmental regulations. ${ }^{214}$ Not all, though, have parallel trade disputes on related issues.

212 See Trujillo, From Here to Beijing supra note 189.

213 See above Section V.

214 See e.g. S.D. Myers, Inc. v Canada, Partial Award, 40 I.L.M. 1408 (hereinafter S.D. Myers); Ethyl Corp. v Canada, 38 I.L.M. 708 (NAFTA Ch. 11 Arb. Trib 24 June 1998) (hereinafter Ethyl Corp); Pope E Talbot, Inc. $v$ Canada, Interim Award (NAFTA Ch. 11 Arb. Trib. 26 June 2000) (hereinafter Pope E Talbot); Methanex Corp. $v$ United States, Final Award of the Tribunal on Jurisdiction and Merits, (NAFTA Ch. 11 Arb. Trib. 3 August 2005), (hereinafter Methanex) available at http:/www.state.gov/documents/organization/51051.pdf; Glamis Gold, Ltd. $v$ United States, Final Arbitral Award (NAFTA Ch. 11 Arb. Trib. 8 June 2009) (hereinafter Glamis Gold), available at http://www.state.gov/s/1/c10986.htm. 
S.D. Myers, Inc. v. Canada, an early Chapter 11 NAFTA case, involved an U.S. corporation treating Canadian polychlorinated biphenyls (PCB) waste through its Canadian subsidiary, which brought the dispute after Canada passed a regulation prohibiting the PCB exports. ${ }^{215}$ The claimant won the case under a national treatment argument, arguing that the Canadian environmental regulation discriminated against the US investor. Interestingly, the NAFTA tribunal looked to WTO interpretations of 'like products' to interpret the 'like circumstances' language under Article 1102 of the NAFTA, though it was much more willing to consider the legitimacy of the measure with respect to Canadian environmental objectives. ${ }^{216}$ Though there was not a comparable trade dispute on the issue, this case did alert the environmental community on the impact that NAFTA, through its investment chapter, could have on domestic environmental regulation. Pope and Talbot $v$ Canada, ${ }^{217}$ on the other hand, involved an investor-state dispute where a US investor in the Canadian softwood lumber business alleged Chapter 11 violations due to a Canadian export ban on softwood lumber. This case was happening against the backdrop of a 1996 US-Canadian Softwood Lumber Agreement and NAFTA Chapter 19 and WTO subsidies disputes concerning Canadian softwood lumber subsidies. Furthermore, in 2004, several Canadian investors initiated investor-state disputes under NAFTA against the US government for passing countervailing duties on softwood lumber imports. $^{218}$ The 'Softwood Lumber cases' illustrate that trade and investment disputes on similar issues involving related parties intersect in ways that ultimately lead toward bilateral negotiated agreements that bring together trade and environmental issues. ${ }^{219}$

The 2009 NAFTA investor-state dispute, Glamis Gold, Ltd v United State, ${ }^{220}$ would converge trade, investment, and environmental issues with the rights of indigenous peoples. Glamis Gold involved a Canadian investor (Glamis) who submitted a proposal to mine on Federal land in southeastern California which was also designated as Native American lands, known as Indian Pass in the California Desert Conservation Area. Around the same time, California passed a law and regulations requiring the backfill of all mine pits, which would have required Glamis to refill the open pit it created. The purpose of the California law was to meet the state's environmental and cultural preservation objectives. Glamis alleged that this law amounted to expropriation of its investment under NAFTA and sued the US government

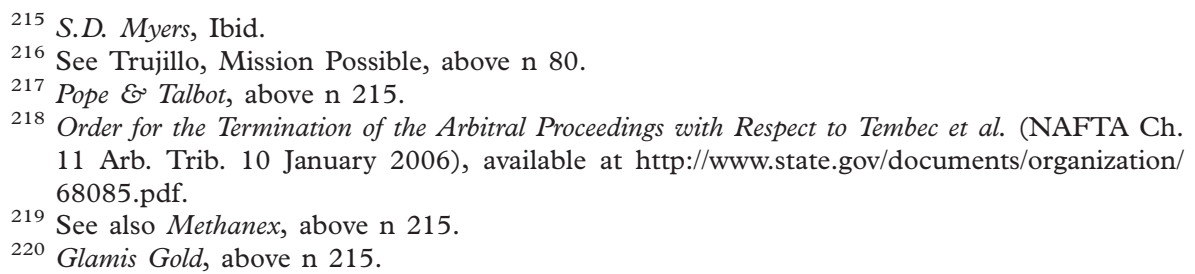


for the value of its mining claim. ${ }^{21}$ After close review of the state regulations and the federal government's responses, the NAFTA tribunal decided against the investor in this case. However, it also elaborated on the importance of recognizing the narrow jurisdiction it had in deciding this case that touched not only upon environmental issues, but also on those of cultural and indigenous people's rights and private versus public rights to property. ${ }^{222}$ Glamis Gold not only brought environmental issues into the domain of investment within a regional trade agreement, it also highlighted the close relationship among trade, investment, environmental protection with those of human rights through cultural protection and indigenous peoples rights. More recently, Lone Pine Resources Inc., a US investor in hydraulic-fracturing, brought a NAFTA Chapter 11 investor-state claim against Canada for Quebec's moratorium on exploration of oil and gas under the St Lawrence River until an environmental impact assessment was done on the effects of hydraulic-fracturing in the region. ${ }^{23}$ This case highlights the convergence among varied stakeholders in the context of energy investment projects and domestic regulatory action intended to address environmental impact concerns and increases the dialogical effects of fragmentation among investment, trade, and domestic governance structures.

\section{Trade and non-trade adjudicatory overlaps: WTO and UNCLOS}

As globalization has taken hold and economies have grown, concerns for the environment have only increased. The environmental community has responded by advocating for the negotiation of MEAs. There are over 250 MEAs. ${ }^{24}$ The question of whether a measure under an MEA could be brought to the WTO has not been resolved. The case that first raised this possibility was Chile - Swordfish case which was submitted both to the WTO and the Law of the Sea Convention (UNCLOS). ${ }^{225}$

Chile - Swordfish began as a result of Chilean legislation for conservation of swordfish, which prohibited the unloading and transit of swordfish catches in Chilean ports. ${ }^{226}$ This affected European vessels fishing for swordfish on the

221 See Ibid, at para 11. The claimant also alleged violations of fair and equitable treatment under Article 1105 NAFTA, claiming that the federal government wrongfully delayed consideration of its proposed project. See Ibid, para 537.

222 See Ibid, at paras 8-9.

${ }^{223}$ Lone Pine Resources Inc. v. The Government of Canada, Notice of Intent to Submit a Claim to Arbitration under Chapter Eleven of the North American Free Trade Agreement, November 8, 2012, available at http:/www.international.gc.ca/trade-agreements-accords-commerciaux/topics-domaines/disp-diff/lone.aspx?lang=eng.

224 See http://www.wto.org/english/tratop_e/envir_e/envir_neg_mea_e.htm.

225 Chile - Swordfish, above n 188.

226 See Peter-Tobias Stoll and Silja Voneky, 'The Swordfish Case: Law of the Sea v. Trade', Max Planck-Institut für ausländisches öffentliches Recht und Volkerrecht (2002), available at http://www.zaoerv.de, p 22-23. See Ley General de Pesca y Agricultura de Chile, articulo 165. 
high seas near Chile. The EU claimed that the Chilean laws violated freedom of transit rules and limits on quantitative restrictions on imports under the GATT. $^{227}$ Under the UNCLOS, Chile argued that bringing the case before the WTO violated UNCLOS and that its actions were allowed under UNCLOS's provisions allowing Coastal States to protect and conserve migratory species such as Swordfish. ${ }^{228}$ The EU alleged that Chile's unilateral legislation violated their right under UNCLOS to fish on the high seas. ${ }^{229}$ The EU's interest in access to Chilean ports was in large part driven by the EU's interest in having better access in the re-export of swordfish to the NAFTA markets, in particular the USA. ${ }^{230}$

In 2001, the parties to the case informed the WTO that they had come to a provisional agreement on the dispute and were suspending further action. ${ }^{231}$ Furthermore, the UNCLOS Tribunal, by agreement of the parties, discontinued its proceedings for this case and eliminated it from its list of cases. ${ }^{232}$ Whether the Chilean legislation was compatible with UNCLOS or WTO law remains uncertain. ${ }^{233}$ However, this case illustrated the delicate relationship between promoting access to trade and policies geared toward conservation of natural resources, especially when those measures are implemented unilaterally by states. Furthermore, it underscores the use of parallel jurisdictions.

A dialogical approach to the Chile - Swordfish case highlights that fragmentation through parallel jurisdictions, where a dispute may be both within the scope of international environmental law and trade law, can in fact contribute to the convergence of trade and environmental issues. The 'conflict' between these two jurisdictional scopes shifted the issues in this dispute from litigation to bi-lateral negotiations between Chile and the EU regarding Chilean port access for swordfish and the creation a multilateral forum for conservation initiatives for the Southeast Pacific. ${ }^{234}$ In January 2001, the EU and Chile reached an 'amicable settlement' to end the WTO and UNCLOS disputes based on primary three pillars: (i) swordfish negotiations would continue through a Bilateral Scientific and Technical Commission (BSTC) which

${ }^{227}$ See GATT Article V, paras 1-3, and XI, para 1.

${ }^{228}$ See UNCLOS, Article 64. There seems to be parallel jurisdiction in this case and it is not clear that the EC was in fact in violation of UNCLOS Article 300 by bringing this case before the WTO. For more discussion, see Stoll and Voneky, above n 225, at 27.

${ }^{229}$ United Nations Convention on the Law of the Sea (UNCLOS), Article 87 and Article 116.

${ }^{230}$ See Marcos Orellana, 'The EU and Chile Suspend the Swordfish Case Proceedings at the WTO and the International Tribunal of the Law of the Sea', ASIL Insights, February 2001, available at http://www.asil.org/insigh60.cfm.

${ }^{231}$ See http://www.wto.org/english/tratop_e/dispu_e/cases_e/ds193_e.htm.

232 See Ibid.

${ }^{233}$ Under GATT law, the Chilean measures would likely be in violation of Articles V and XI, unless they came under exceptions that could justify the measures under Article XX of GATT. See GATT Article XX(b) and (g). For more discussion, see Stoll and Voneky, above n 227, at 28-33.

${ }^{234}$ See Orellana, above n 231. 
would consider scientific evidence regarding conservation of swordfish, (ii) Chile would provide EU vessels access to specific Chilean ports within an agreed program that would also allow for the acquisition of data to be used by the BSTC in assessing the state of swordfish stocks, and (iii) a commitment to creating a multilateral framework for dealing with swordfish conservation in the Southeast Pacific. ${ }^{235}$ Interestingly, along with the EU Fisheries Commissioner, Fischler, and Chilean counterparts, the Director-General of the WTO, Pascal Lamy, played an active role bringing agreement between the two parties. ${ }^{236}$ One report states that ' $[\mathrm{t}]$ he settlement strikes a balance between taking due account of the requirements of the multilateral trade system and of an effective conservation and management of natural resources'. ${ }^{237}$ Therefore, the dialogical impact is clear. Not only did the adjudicatory capacity of the WTO play an important role, but the administrative capacity, through the negotiating power of the Secretariat, also was significant in bringing convergence to the issues of trade and sustainability. ${ }^{238}$

\section{TRADE COMPLIANCE, REGULATION, AND 'GREENING' STRATEGIES}

Because of climate change concerns, it is increasingly more difficult to discuss the trade and environment relationship without also addressing sustainability issues and the push towards green economic growth. While the administrative and adjudicatory functions of the WTO grapple with the ways in which trade jurisprudence may better accommodate for domestic policies intended to address climate change concerns, the UNEP and other UN organizations are engaging in multilateral dialogue to develop strategies for sustainable development.

The 2012 United Nations Conference on Sustainable Development $($ Rio +20$)$ focused on sustainable development, launching a process to develop a set of Sustainable Development Goals and adopting guidelines of

${ }^{235}$ See EU and Chile Settle WTO/ITLOS Swordfish Dispute, European Union @ United Nations Partnership in Action, available at http://www.europa-eu-un.org.

${ }^{236}$ See Letter from the European Union, 22 June 2010, Official Journal of the European Union, available at http://eur-lex.europa.eu/LexUriServ/LexUriServ.do?uri=OJ:L:2010:155: 0010:0018:EN:PDF; http://eur-lex.europa.eu/LexUriServ/LexUriServ.do?uri=OJ:L:2010: 155:0003:0009:EN:PDF. See also, Summary of Treaty, EU Treaties Office Database, available at $\mathrm{http}: / /$ ec.europa.eu/world/agreements/prepareCreateTreatiesWorkspace/treatiesGene ralData.do?step $=0 \&$ redirect $=$ true\&treatyId $=8562$. In 2010 , the EU and Chile agreed that an Exchange of Letters would serve as an 'Understanding concerning the Conservation of Swordfish Stocks in the South-Eastern Pacific Ocean', replacing the Provisional Agreement they had signed in 2001. This Understanding confirmed many of the original initiatives under the Provisional Agreement, but also froze the swordfish fishing levels to the levels in 2008 or 'at the maximum historical peak' and invited outside observers with a legitimate interest in swordfish conservation to the multilateral consultation efforts.

${ }^{237}$ See EU and Chile Settle WTO/ITLOS Swordfish Dispute, above n 236.

${ }^{238}$ But note that many environmentalists would take a position that the WTO is not the proper forum to deal with environmental issues. See e.g. http://www.citizen.org/trade/wto/ ENVIRONMENT/. 
green economy policies. ${ }^{239}$ Furthermore, it recognized the need to work with other relevant organizations such as the WTO and reaffirmed the right to use the provisions in TRIPS Agreements, the Doha Declaration on the TRIPS Agreement and Public Health, and the decision of the WTO General Council on 30 August 2003 on the implementation of paragraph 6 of the Doha Declaration on the TRIPS Agreement and Public Health. It also reaffirmed the commitment in the Johannesburg Plan regarding the elimination of subsidies that contribute to illegal and unregulated fishing and overcapacity. $^{240}$ Participants in Rio +20 also urged the completion of the Doha Development Agenda in a balanced way and, 'with a view to strengthening the multilateral trading system'. ${ }^{241}$ Participants included 193 countries, businesses and civil society partners. In the outcome document, participants elaborated the ways in which green economy policies can be a tool to advancing sustainable development. Furthermore, it addressed the ways in which energy is relevant to sustainability. ${ }^{242}$ They also adopted a 10 -year framework on a Program for sustainable consumption and production. ${ }^{243}$

Though Rio +20 resulted in voluntary commitments to put sustainable development into action, specifics and the means to enforce these commitments were lacking. Perhaps the greatest contribution of the Summit was to move the dialogue forward, bringing together many stakeholders as well as developed and developing countries. Furthermore, it formally linked economic development with sustainable development; which in turn, may influence the way trade regimes will deal with environmental policies affecting trade compliance, as the Rio +20 Outcome Document suggests.

While there is no specific definition of a green economy, the UNEP provides a holistic understanding that a green economy 'results in improved human well-being and social equity, while significantly reducing environmental risks and ecological scarcities. ${ }^{244}$ Therefore, principles of a green economy are closely tied to economic development, as reflected in the 2000 Millennium Goals. ${ }^{245}$ However, main indicators for economic growth; namely, Gross Domestic Product (GDP), traditionally have not accounted for environmental externalities. ${ }^{246}$ Rio +20 acknowledged in a draft

239 See Future We Want: Outcome Document, available at http://sustainabledevelopment.un.org/in dex.php?menu=1298.

240 Ibid paras 78, 142, and 173.

241 Ibid para 282.

242 Ibid paras 125-29.

243 Ibid paras 224-26.

${ }^{244}$ UNEP 2010, 'What is the 'Green Economy'?' available at http://www.unep.org/greeneconomy/AboutGEI/WhatisGEI/tabid/29784/Default.aspx.

245 See United Nations, Millenium Development Goals Indicators, http://mdgs.un.org/unsd/md $\mathrm{g} /$ host.aspx?Content=indicators/officiallist.htm (15 January 2008). See generally, Amartya Sen, Development as Freedom (Delhi: Oxford University Press, 2000).

246 See UNEP 2011 Report, Towards a Green Economy: Pathways to Sustainable Development and Poverty Eradication, para 1.2. 
document that gross domestic product (GDP) is not a comprehensive way of assessing a country's development if it does not include the state of the environment. However, developing countries, which are the most impacted both by climate change and by environmental regulations that can affect their market accessibility, are hesitant to agree to any policy of sustainability that would stunt their economic growth. These concerns were reflected in the TBT trade negotiating history when a 1995 WTO Secretariat note concluded that many of the negotiating nations, for example Mexico, 'were of the view that standards based inter alia on PPM's unrelated to a product's characteristics should not be considered eligible for being treated as in conformity with the TBT Agreement. ${ }^{247}$ Furthermore, pursuant to Article 31 of the Doha Agenda, negotiators attempted to eliminate tariff and non-tariff barriers on environmental goods and services (EGS); however, they struggled to agree on what products constituted EGS. ${ }^{248}$ Developing countries, in particular, were concerned with PPM-based environmental goods. ${ }^{249}$ As labeling becomes one way to incentivize green production methods, it will become increasingly important for trade regimes to address trade compliance issues of PPM-based environmental goods.

Labeling schemes are examples of less formal regulatory norms, deriving both from public and private networks, many of which are transnational and adopted through industry practice and/or free market forces. ${ }^{250}$ In this new form of regulation, NGOs and private actors are working with intergovernmental organizations and governments to help create and monitor such standards. ${ }^{251}$ Eco-labels, for example, identify the product's impact on the environment based on the life cycle of the product and provide information to consumers about the relative environmental quality of a product. Several eco-labeling schemes, both public and private and even public/private regulatory schemes, turn to the international global standards of the International Organization for Standardization (ISO) and Global Eco-labeling network for guidance. The ISO, like the Codex Alimentarius Commission, was established through the WTO to help set harmonized standards for creating

247 Negotiating History of the Coverage of the Agreement on Technical Barriers to Trade with Regard to Labeling Requirements, Voluntary Standards and Processes and Production Methods Unrelated to Product Characteristics, 3(c), WT/CTE/W/11 (Aug. 29, 1995) (further analysis in 10351). See also Section III.B.1 for a discussion on PPM's.

248 See Mahesh Sugathan, 'A Doha Round Deliverable for Climate Change?', 1(2) Bridges Trade BioRes Review, Vol 1, No. 2 (Dec. 2007).

249 See Gaëlle Balineau and Jaime de Melo, Stalemate at the Negotiations on Environmental Goods and Services at the Doha Round, at 7-8 October 2011 working draft, available at http://www.ferdi.fr/uploads/sfCmsContent/html/112/P28.pdf.

250 See Koh, above n 28.

251 For example, Rainforest Alliance, the Brazilian IMAFLORA, and the Brazilian coffee industry association, ABIC, are working together to certify Brazilian coffee as 'sustainable', using the Rainforest Alliance Certified seal. See The Rainforest Alliance and IMAFLORA Join Forces with Brazilian Coffee Industry, 23 November 2009, available at http://www.rainfor estalliance.org/newsroom/news/imafloraabic. 
environmentally safe products and food standards in the case of Codex. Governments may look to their own national standards or international standards such as ISO to set up their own criteria. For example, the German Blue Angel label, state created and monitored, is a voluntary label and applies to consumer products and services, following the international standards found under the ISO and Global Ecolabeling Network. ${ }^{252}$ The Blue Angel label has become so standard and prestigious that it has contributed to changing consumer behavior and the German Federal Environment Agency has monitored these changes and incorporated them into established requirements and test methods for products. By public and private regulatory bodies adopting these global standards in their labeling schemes, global norms can trickle down toward the domestic and become transnational. ${ }^{253}$

This less formalized means of cross-fertilizing trade and environmental standards is perhaps the most organic and evolving in recent WTO jurisprudence since WTO panels tend to look to international standards for guidance when adjudicating domestic regulatory measures. ${ }^{254}$ The changing regulatory landscape has distinguishing features for future WTO adjudication of regulatory measures: (i) transnational and global regulatory norms are converging and the state plays a less important role in their creation and enforcement, ${ }^{255}$ and (ii) the WTO preference for multilateral actions and harmonization of international standards, rather than unilateral actions by states may result in transnational regulatory norms increasingly becoming more formalized (or not) into the global system. ${ }^{256}$

Furthermore, recent preferential trade agreements are encouraging voluntary regulatory norms that are both market-driven and transnational. The Central American Free Trade Agreement, ${ }^{257}$ which contains a chapter on the environment, recognizes that environmental policy may be encouraged

252 Blue Angel follows ISO 14020, 140211, 14022, 14025. See http://www.blauer-engel.de/en/ blauer_engel/index.php.

253 Greg Shaffer, 'Transnational Legal Process and State Change: Opportunities and Constraints', NYU IILJ working paper 2010/4, available at http://iilj.org/publications/ 2010WorkingPapers.asp (visited 14 July 2013). (distinguishing between global law which are 'universal norms [that] are created and diffused globally in different legal domains' and transnational law which 'comprises legal norms that cross borders and thus apply to parties located in more than one jurisdiction'.).

254 US - Tuna II AB Report, above n 23 paras 350-352;359; 379.

255 See Kenneth W. Abbott and Duncan Snidal, 'Strengthening International Regulation through Transnational New Governance: Overcoming the Orchestration Deficit', 42 Vanderbilt Journal of Transnational Law 2 (2009) (discussing the 'Transnational Governance Model' where private actors and civil society, rather than the state, take on an increased role in setting and enforcing regulatory standards).

256 See e.g. US-Tuna II AB Report, above n 23, paras 384-386; 390.392,394; 396-399; 401 (deciding that AIDCP was not an international organization recognized for setting international standards). See SPS Agreement, Article 3; TBT Agreement, Article 2.4.

257 Central American Free Trade Agreement, Aug. 5, 2004, 2006 U.S.T. LEXIS 119, 51 I.L.M. 1226, [hereinafter CAFTA]. 
and best implemented by private entities and so encourages the establishment of voluntary mechanisms through businesses, local communities, and non-governmental organizations in order to improve environmental performance. $^{258}$ The recent US-Peru Free Trade Agreement also encourages similar market-based voluntary mechanisms. ${ }^{259}$

As regulatory paradigms shift and consumers become more aware of sustainability concerns, traditional notions of what constitutes economic development need to be reevaluated. Adjustments will have to be made not only to the methods of measuring economic development to account for environmental externalities, but also to current economic structures so as to shift production methods and consumption patterns toward 'green' results. ${ }^{260}$ Such adjustments have trade-offs both for the developed and developing countries. Though many developing countries are concerned that such adjustments can translate into protectionist measures that impede their ability to have access to markets, other emerging economies like China and Brazil are at the forefront of green technologies. ${ }^{261}$ Though much of the discourse for trade and sustainability has been on the need to develop renewable resources as energy demands increase and find 'cleaner' inputs to production processes, issues around food security, agriculture, and timber taint optimism for the increased use of renewable resources. ${ }^{262}$

Striking a balance between legitimate regulatory measures intended to incentivize green growth versus those intended to protect domestic markets is no easy task. Trade regimes are arguably designed to deal with these challenges, through the narrow lens of the provisions in the GATT and related Covered Agreements that address non-tariff barriers. Whether they can serve as governance mechanisms for managing 'green trade' is less clear, especially if regulation shifts from governments to the private sector or a public/private hybrid. At the 2013 World Economic Forum in Davos, WTO DirectorGeneral stated that the environmental sustainability issue was not being adequately addressed: 'On the environment, we are moving this planet backwards in terms of well-being, and that's why I think the environment should

258 Ibid, Chapter 17

259 See Article 18.5 US-Peru Free Trade Agreement.

260 See Report by a Panel of Experts to Second Preparatory Committee Meeting for United Nations Conference on Sustainable Development, 'The Transition to a Green Economy: Benefits, Challenges and Risks from a Sustainable Development Perspective' by José Antonio Ocampo at p 7, available at http://www.unep.org/greeneconomy/Portals/88/docu ments/research_products/UN-DESA,\%20UNCTAD\%20Transition\%20GE.pdf.

261 See World Bank Supporting Report 3, 'Seizing the Opportunity of Green Development in China', available at http://www.worldbank.org/content/dam/Worldbank/document/SR3-229292.pdf. See also Shai Oster, 'World's Top Polluter Emerges as Green-Technology Leader', The Wall Street Fournal, 15 December 2009. Approximately 46\% of Brazil's primary energy production is from renewable energy. See Balanço Energético Nacional ano base 2011 from the Brazilian Ministry of Mining and Energy, available at https://ben.epe.gov.br/down loads/Relatorio_Final_BEN_2012.pdf.

262 See 2010 World Trade Report: Trade in Natural Resources, at 97-105 and 183-91, available at http://www.wto.org/english/res_e/publications_e/wtr10_e.htm. 
be a priority. ${ }^{263}$ Though questions remain as to the extent that trade regimes can and should play in the push towards environmental sustainability, trade regimes have increasingly become a part of the strategies for green economic growth, further highlighting that environmental norms will continue to converge with trade ones.

\section{CONCLUSION: LESSONS FROM USING A DIALOGICAL APPROACH}

The relationship of trade to the environment and the way in which important 'linkages' have been established over time between the two camps is not new. Others have written on the importance of the administrative capacity of the WTO and the challenges of expanding the adjudicatory capacity of the WTO beyond trade matters. ${ }^{264}$ Less has been written on the dialogical aspects of the internal dynamics of the adjudicatory and administrative capacities of trade regimes and of the impact that fragmentation has in enhancing cross-fertilization between trade and environmental issues. This article aspires to fill that gap. Furthermore, it illustrates that such convergence can also shape trade law and influence the sustainable development discourse, as is evidenced in the Rio +20 Outcome Document. The interfaces span beyond the internal structures of the trade regime, even if much of the convergence has taken place within the regime itself. The interaction among various regimes has important implications for the ways in which trade and environmental concerns overlap. Collision among jurisdictional domains and legal norms not only increases fragmentation, but also creates normative space for dialogue and new visions of the way the relationship among trade and environmental issues will evolve over time. ${ }^{265}$ Jurisdictional choices matter as to how conflicts are settled and how issues concerning trade and environment are resolved outside the realm of trade. Adjudicatory conflict may lead to negotiations, the creation of new environmental regimes, and to new mechanisms for regulation many of which transform the role of the state into a 'manager' of competing regulatory norms rather than the creator or enforcer of them. ${ }^{266}$ In addition, these dynamics in and around the institutional structure of the WTO contributes to the legitimacy of its overall legal framework, allowing trade norms to seep into other non-trade jurisdictional domains.

${ }^{263}$ See World Economic Forum in the 'Global Agenda Outlook 2013', p 8, available at http:// www.weforum.org/reports.

${ }^{264}$ See e.g. Jeffrey L. Dunoff, 'The Death of the Trade Regime', 10 European Journal of International Law 733 (1999); Jeffrey L. Dunoff, 'Lotus Eaters: Reflections on the Varietals Dispute, the SPS Agreement, and the WTO Dispute Resolution', 1 Health Regulation in the WTO, 2006.

265 Teubner and Korth, 'Two Kinds of Legal Pluralism,' above n 25.

${ }^{266}$ See Paul Berman, Global Legal Pluralism, above note 200. 
A dialogical approach to the trade and environment interplay illuminates three main factors. First, the relationship between the adjudicatory and administrative functions of the WTO matters and the two reinforce one another. Each within its own capacity can serve as a catalyst for more dialogue among trade and environmentalists and may ignite the recognition for new environmental agreements. The adjudicatory capacity also serves as a legitimizing tool for the work done within the administrative capacity of the WTO. The WTOs adjudicatory function and its adherence to the rule of law and capacity to use judicial discretion in the interpretation of that law can set the course for how future negotiations in this area will evolve, both within the administrative capacity of the trade regime and outside the WTO itself. Furthermore, through new interpretations of WTO law and willingness to incorporate non-trade elements into applying that law, adjudicatory panels are allowing environmental concerns to 'seep' into trade concepts. However, trade norms are also traveling outside the traditional parameters of the trade regime, as evidenced in some multilateral environmental agreements and in recent sustainability summits. In this way, cross fertilization, both inwards and out, is taking hold.

Second, a dialogical approach demonstrates that there are multi-centered points for convergence for trade and environmental issues. In addition to the multilateral framework, many of the sources of convergence for trade and the environment have been regional and domestic. Therefore, the ways in which the multilateral interacts with the regional and bilateral regimes are important when considering the trade and environment interplay. Furthermore, the interaction among trade and non-trade regimes, including investment regimes, is another means for convergence of trade and environmental issues. This interaction, though, also raises concerns regarding forum shopping and increased fragmentation. But it is within the collision of various jurisdictional and legal domains that dialogue and new ways of thinking about the relationship have emerged. ${ }^{267}$

Finally, fragmentation has rendered the relationship to be organic and less hierarchical. The adjudicatory processes of the WTO have played an important role in helping to change the discourse as between the environment and trade from one that is separated by different normative goals to one that allows for more convergence. This convergence, though, has also emerged from its administrative capacity, allowing for a political forum for broader discourse among members of the global community regarding trade and sustainable development. This process shapes how international environmental law and issues around sustainability are evolving and ensures that the concerns of trade remain part of the discourse. In this way, the scope of the trade regime has

267 The author concedes that there are times when disputes do not result in dialogue; however, such instances should be seen as part of an ongoing, organic process that contributes towards the emergence of a 'shared environmental sustainability' discourse. 
expanded, both by exporting trade rules into other legal domains and by influencing the way trade and non-trade issues converge. ${ }^{268}$

Key to a dialogical approach to the trade and environment interface is that the relationship is evolving from several directions, top-down, bottom-up, horizontal and vertical ways of bringing convergence, and that the state is not the only primary player in this process. ${ }^{269}$ The participation of non-state parties into the trade framework is a significant phenomenon for enhancing dialogue and cross-fertilization between the camps. The work of NGOs and standardizing organizations have found their way into trade regimes, both through their adjudicatory and administrative capacities and in formal and informal ways. Despite this influence, though, the trade system does have a strong voice in how environmental regulation is being shaped and in the changing role of states in establishing and enforcing regulatory norms. If we can imagine a 'shared environmental discourse' emerging, it is one with an eye toward furthering trade principles and "green" economic growth, but it is less clear if this in fact better aligns economic development with environmentally sustainable development principles, despite the ideals of the Millennium Development goals and the voluntary commitments of Rio +20 .

Clearly, more understanding and dialogue is needed between the two camps, both of which are siloed in their jurisdictional scopes and legal frameworks, but are increasingly becoming more and more linked. Though there is increased convergence, this should not necessarily be the end goal for a model of sustainable development. The ways in which the convergence takes place must be taken into account in order to have clarity on the values and norms that are shaping current and future policies around sustainability and economic development.

In light of the recent global financial crisis, questions have emerged regarding the applicability of our current capitalist system in today's world and whether other values beyond profit enhancement should also be incorporated into a market economy. ${ }^{270}$ In a globalized world of multilateral, regional, bilateral, and domestic legal frameworks, fragmentation, rather than harmonization, predominates notions of global governance. Regime and legal fragmentation can

${ }^{268}$ See e.g. Energy Charter Treaty, 'Trade in Energy', available at http://www.encharter.org/ fileadmin/user_upload/document/WTO_Rules_applying_to_the_ECT_-_2002_-_ENG.pdf. (WTO rules applying to trade in energy).

269 But see Robert O. Keohane and David G. Victor, Regime Complex for Climate Change, Discussion Paper 2010-33, Harvard Project on International Climate Agreements, January 2010, available at http://belfercenter.ksg.harvard.edu/files/Keohane_Victor_Final_2.pdf; Raustiala and Victor, above n 200.

270 Amartya Sen, 'Capitalism Beyond the Crisis', The New York Review of Books (2009), available at http://www.nybooks.com/articles/archives/2009/mar/26/capitalism-beyond-thecrisis/?pagination=false (explaining that in his first book, The Theory of Moral Sentiments, Adam Smith 'investigated the strong need for actions based on values that go beyond profit seeking'.). 
pose new opportunities for dialogue and the creation of transnational norms that can assist in testing new visions of economic development that are not only driven by profit enhancing mechanisms and measures of GDP, ${ }^{271}$ but also better align the importance of environmental sustainability with that of economic development.

271 James M. Cypher and James L. Dietz, The Process of Economic Development (Routledge, 2008), at 31. 